San Jose State University

SJSU ScholarWorks

Master's Theses

Master's Theses and Graduate Research

1994

\title{
The effects of cooperative learning on the self-esteem of students learning English as a non-native language
}

Michelle M. Dimas

San Jose State University

Follow this and additional works at: https://scholarworks.sjsu.edu/etd_theses

\section{Recommended Citation}

Dimas, Michelle M., "The effects of cooperative learning on the self-esteem of students learning English as a non-native language" (1994). Master's Theses. 903.

DOI: https://doi.org/10.31979/etd.hqjp-u7q8

https://scholarworks.sjsu.edu/etd_theses/903

This Thesis is brought to you for free and open access by the Master's Theses and Graduate Research at SJSU ScholarWorks. It has been accepted for inclusion in Master's Theses by an authorized administrator of SJSU ScholarWorks. For more information, please contact scholarworks@sjsu.edu. 


\section{INFORMATION TO USERS}

This manuscript has been reproduced from the microfilm master. UMI films the text directly from the original or copy submitted. Thus, some thesis and dissertation copies are in typewriter face, while others may be from any type of computer printer.

The quality of this reproduction is dependent upon the quality of the copy submitted. Broken or indistinct print, colored or poor quality illustrations and photographs, print bleedthrough, substandard margins, and improper alignment can adversely affect reproduction.

In the unlikely event that the author did not send UMI a complete manuscript and there are missing pages, these will be noted. Also, if unauthorized copyright material had to be removed, a note will indicate the deletion.

Oversize materials (e.g., maps, drawings, charts) are reproduced by sectioning the original, beginning at the upper left-hand comer and contimuing from left to right in equal sections with small overlaps. Each original is also photographed in one exposure and is included in reduced form at the back of the book.

Photographs included in the original manuscript have been reproduced xerographically in this copy. Higher quality $6^{\prime \prime} \times 9^{n}$ black and white photographic prints are available for any photographs or illustrations appearing in this copy for an additional charge. Contact UMI directly to order.

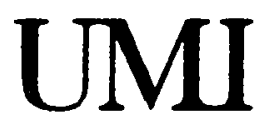

A Bell \& Howell information Company 



\title{
THE EFFECTS OF COOPERATIVE LEARNING ON THE SELF-ESTEEM OF STUDENTS LEARNING ENGLISH AS A NON-NATIVE LANGUAGE
}

\author{
A Thesis \\ Presented to \\ The Faculty of the Department of Teacher Education \\ San Jose State University \\ In Partial Fulfillment \\ of the Requirements for the Degree \\ Master of Arts \\ by \\ Michelle M. Dimas \\ December 1994
}


UMI Number: 1361161

UMI Microform Edition 1361161

Copyright 1995, by UMI Company. All rights reserved.

This microform edition is protected against unauthorized copying under Title 17 , United States Code.

\section{UMI}

300 North Zeeb Road

Ann Arbor, MI 48103 
(C) 1994

Michelle M. Dimas

ALL RIGHTS RESERVED 


\section{APPROVED FOR THE DEPARTMENT OF EDUCATION}

The Division of Teacher Education

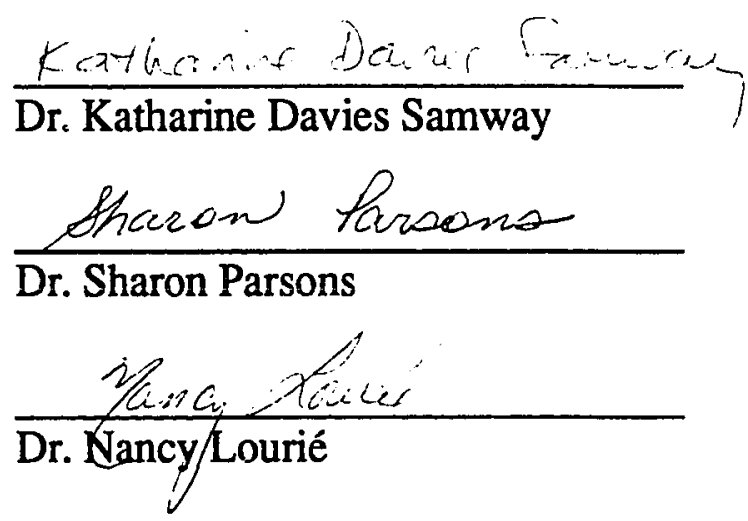

APPROVED FOR THE UNIVERSITY Th. Lou Vewandoweti 


\section{ABSTRACT \\ THE EFFECTS OF COOPERATIVE LEARNING ON THE SELF-ESTEEM OF STUDENTS LEARNING ENGLISH AS A NON-NATIVE LANGUAGE \\ by Michelle M. Dimas}

This project examines the effects of cooperative learning strategies on the sclf-esteem of students learning English as a non-native language (ENNL).

The research question was: Does cooperative learning have an effect on an ENNL student's self-estcem? Threc subquestions involving the ENNL student's role and level of participation in the cooperative learning group were also asked.

Case studies of three sixth-grade ENNL students were done by a teacher-researcher. Data were collected through interviews with students, school cumulative files, attitudinal surveys, audio tapes of students' cooperative learning groups, field notes, and video tapes.

Analysis of the data included transcribing and coding the students' utterances and interviews, preparing data tables, and tabulating survey responses. All data were examined for meaningful patterns.

Findings indicated that a positive group placement can positively affect ENNL students' self-esteem. Positive placements included participation in activity, two-way conversations, feelings of contributing to and being helped by the group. 


\section{Dedication}

This paper is dedicated to my family.

To my daughters, Aubrie and Brenna who, with patience and understanding, allowed me the time to pursue this dream.

To my husband, Dalc who offered support not only as my life partner, but as a

sounding board for my ideas and as a clerical assistant. Without him, this paper would not have been written.

To my mother, Shirley Bordoni who, when I wanted to call it quits, offered me the just the right encouragement I needed to continue.

And special thanks to Dr. Katharine Davies Samway for the hours she spent reading this paper and for providing the type of feedback that allowed me to refine my thinking and writing to convey the findings of this research project. 


\section{Table of Contents}

Tables.......................................................................... vii

Chapter One: Introduction to the Research Project.....................................

Rationale for this Research ............................................2

Statement of Purpose ....................................................... 4

Constraints on the Research............................................4

Relevance of the Study ................................................ 4

Chapter Two: A Review of the Current Literature.....................................6

The English as a Non-Native Language Student ...........................6

Educating ENNL Students ............................................. 8

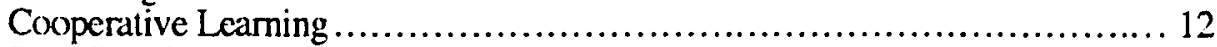

Benefits of Cooperative Learning ....................................... 14

Cooperative Learning and the ENNL Student ............................ 16

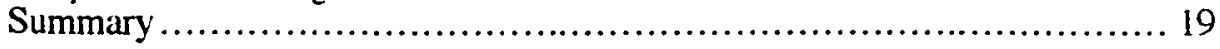

Chapter Three: The Research Methodology......................................... 21

Rescarch Setting: The Science Lab................................... 21

The Students ...................................................... 25

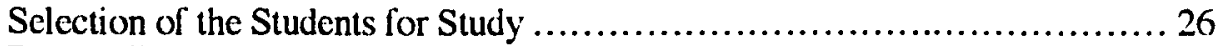

Data Collection......................................................... 27

Data Analysis ............................................................ 31

Data Analysis Part One: Audio Tapes and Observations..................... 32

Data Analysis Part Two: Attitudinal Surveys .............................. 35

Chapter Four: Chandra, Minh, and David: Three Case Studies ........................ 36

First Casc Study: Chandra ............................................... 36

Sccond Case Study: Minh.............................................. 51

Third Casc Study: David .............................................. 67

Cooperative Group Placcment: An Important Factor......................... 83

Chapter Five: A Discussion of the Data....................................... 86

Cooperative Lcarning and Self-esteem.................................... 86

Revisiting the Subquestions............................................ 87

Qucstions Raised by this Research..................................... 88

Classroom Implications................................................ 93

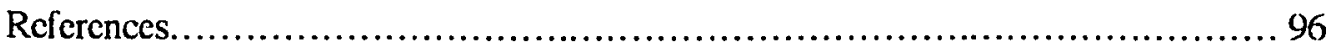

Appendix A .................................................................... 99 


\section{Tables}

Table 1: Types of Utterances in Chandra's First Group Placement ...........43

Table 2: Class of Utterances in Chandra's First Group Placement...........43

Table 3: Types of Utterances in Chandra's Second Group Placement........51

Table 4: Class of Utterances in Chandra's Second Group Placement.........51

Table 5: Types of Utterances in Minh's First Group Placement..............60

Table 6: Class of Utterances in Minh's First Group Placement.............61

Table 7: Types of Utterances in Minh's Second Group Placement...........69

Table 8: Class of Utterances in Minh's Sccond Group Placement ...........69

Table 9: Types of Utterances in David's First Group Placement .............80

Table 10: Class of Utterances in David's First Group Placement ............80

Table 11: Class of Utterances in David's Second Group Placement ..........86

Table 12: Types of Utterances in David's Second Group Placement .........88 


\section{Chapter One}

\section{Introduction}

This thesis is teacher rescarch, designed and conducted by a classroom teacher. It arose out of questions I asked while observing students in my own classroom. Students in my room, the science lab, work in cooperative learning groups known as teams. I use cooperative learning strategies regularly in my classroom and have eagerly defended them against any who called these strategies just another fad in the ever-evolving world of educational methods. After all, the educational research over the past ten years (Ascher, 1986; Conwell, Picl, \& Cobb, 1988; Gallien, 1988; Yager, Johnson, Johnson, \& Snider 1985) has indicated that cooperative learning positively influences students' academic achievement, intergroup relations, self-esteem, and attitudes towards others.

Looking around the class room, one will see the elements of cooperative learning. Tcam work, in which all group members are involved, is stressed and even graded. Social skills such as sharing, taking turns, making supportive, positive comments to teammates, and eye contact are taught. In this room students learn from cach other and from having to explain their ideas to others. Therefore, I encourage students to talk, to work together on labs, and to share their thoughts with one another. My room is both a noisy and productive lcarning environment.

Over the years, however, as I looked around my room, I began to notice that my students who were not native English speakers were sometimes not talking, or involved in the activity. Sometimes, they were not even smiling. These were students who had attempted and used English in other settings within the school. They had spoken with me on an individual basis and I had heard them with their friends at recess and linch. Why weren't they participating in cooperative learning activities? Were they unhappy? Were they

unintcrested? Were they reaping all the benefits of cooperative lcaming? Was cooperative 
lcarning as beneficial for students who were developing English as a non-native language as it was for those who were English proficient? Was I, as a teacher, doing what was best for all my students? I had what I felt were some worthwhile questions and so I began to look for some answers.

\section{Rationale for this Research}

In the six short years since I began teaching, the composition of my classes has changed. More of my students speak little or no English and it seems a daily challenge to make my subject of science meaningful to all of my students. My classroom experience is not unique. Classrooms all over California are experiencing an increase in students who are developing English as a non-native language (ENNL). In the four years between 1986 and 1990, the number of ENNL students in California schools increased almost 52\% from 567,564 to 861,531 students (Olsen, 1991). Current second-language acquisition theory states that these students should be educated bilingually, thereby allowing them to continue to develop academic competence and to acquire a second language (Cummins, 1981). Cummins explains, in his theory of common underlying proficiency, that academic skills that are developed in a student's first language automatically transfer to a student's second-or third or fourth-language. Unfortunately, in California public schools, almost onc hundred languages are spoken and there exists a shortage of qualified bilingual teachers, making bilingual education for most ENNL students impossible (Olsen \& Mullen, 1990). These students are most of ten placed in a regular classroom for a great portion of their school day. Here they struggle to learn the academic content of the subjects which are being taught in English, their new language.

Many teachers struggle to create an environment where learning can take place for the ENNL student. One strategy recommended for use with this student in the heterogeneous classroom, a classroom made up of students with different languages, cultures, and 
abilities, is coopcrative lcarning (CL) (Calderón, 1989; Jacob \& Mattson, 1987; Levinc, 1984). There has been rescarch on CL with ENNL students and its effect on language production and proficiency. This research has indicated that using CL strategies, rather than traditional teacher-whole class methods, results in greater improvement in English proficiency for the ENNL student (Cohen, 1990). Students have an opportunity for an increase in the quantity of language practice and they improve the quality of their language usage (Long \& Porter, 1985). Bejarano (1987) found that CL strategies, when compared to traditional whole class methods, helped promote listening comprehension in English as a second language (ESL) students.

There has been additional research on CL strategies conducted with English speakers. These studies (Conwell, Piel, \& Cobb, 1988; Gallien, 1988) have shown that CL can benefit English speaking learners by increasing academic achievement, breaking down social prejudices, and increasing self-esteem and creating an atmosphere that allows risk taking (Ascher, 1986; Yager, Johnson, Johnson, \& Snider 1985).

The research with ENNL students and CL strategies is not yet as extensive as that done with native English speakers. Left unanswered by the current research on CL with the ENNL student were questions regarding the benefits of this teaching strategy on selfesteem. When addressing this benefit, the researchers simply cited other research which did not include or focus on ENNL students. It was conducted with CL groups in which members shared a common language-English. I could not find research conducted with ENNL students that specifically addressed the effects of CL strategies on students' selfesteem, research where the effects on the ENNL students were directly measured.

Learning a non-native language while in the $\mathrm{CL}$ group structure would seem to be an important variable. Should it not be considered before automatically assuming that the benefits found in using CL with all English-speaking students apply in situations where the students are developing English as a non-native language? This question led to others. 
What roles are ENNL students playing in their CL groups? Are they full-fledged team members, intimately involved with the group task, or are they simply sitting uninvolved among the team members? Does their participation in the group, or lack thercof, have an effect on their self-esteem? These formed the subquestions that lead to the basis of this research- "Does cooperative learning have an effect on an ENNL student's self-cstcem?"

\section{Statement of Purpose}

The purpose of this research is to determine whether CL strategies have an effect on the ENNL student's self-esteem. Further, it examines how the ENNL student participates within the CL group and if varying levels of participation affect his or her self-esteem.

\section{Constraints on the Research}

This rescarch is limited by several factors. It is limited by the fact that the students did not always understand the questions used on the surveys and during the interviews due to their lack of fluency in English. The only common language that I shared with the students was English. The research is also limited by the fact that I am both the researcher and the classroom science teacher and sometimes had to function as a teacher to the exclusion of the researcher role. For example, during a multiple-day lab on electrical circuits I would have liked to have spent a greater amount of time observing the ENNL students in their groups. However, I had to spend a majority of my time helping the nine CL groups solve "technical" problems like burnt-out light bulbs, broken wires, and batteries low on energy so that the desired learning outcomes could occur. Finally, this research is limited by the number of students involved, three.

\section{Relevance of the Study}

The study is significant in that it combines observation, student surveys, and student interviews in an attempt to gain a well-rounded view of the effect of CL on the ENNL 
student's self-esteem. I chose to ask the students for their perceptions and explanations of their actions and thoughts instead of relying solely on my own assumptions, observations, and perceptions of what had occurred. This allows a more accurate interpretation when dcaling with the issues of self-esteem and self-perception. I believe it is important to get the learner's perspectives on what has occurred. This research is also relevant because it was done by a classroom teacher and comes from the perspective of a person involved in the day-to-day education of ENNL students, which is a perspective of ten overlooked in educational research. 


\section{Chapter Two}

\section{A Review of the Current Literature}

The following review' begins with a description of ENNL students and how English as a non-native language is acquired according to current second language acquisition theory. The review continues with a look at the philosophy of cooperative leaming and current research on the topic since cooperative learning is a suggested strategy for use with ENNL students that are placed in mainstream classrooms (Calderón, 1989; Cohen, 1990; Slavin, 1988). The initial research on cooperative learning in the 1970s and early 1980 s involved English speakers and established many benefits for this teaching strategy, so one must first look at this research to understand the more limited research on cooperative learning with the ENNL student. The possible benefits of cooperative learning for the ENNL student are discussed, and the chapter closes with a discussion of the limitations of the current research and questions these limitations raise.

\section{The English as Non-Native Language Student}

The ENNL student is a person learning English as a Non-Native Language. My use of the term ENNL refers to both children who were born in the United States and those who arrived after their birth. Though they share the need for fluency in the English language to succed in the school environment and mainstream America, ENNL students' backgrounds vary greatly. Some ENNL students will have previous academic experience, some come from families that are highly educated, some will be literate in their first language and some will have never seen a school or a book. Their positions and responsibilities within the family will differ, as will the reasons for their families' emigration. The parents' sociocconomic levels and expectations for the role of their child's education will also vary. In California schools, these students are labeled Limited English Proficient (LEP). According to Handscombe (1989), even with the variety among their backgrounds, LEP 
students can be grouped into four subgroups: immigrants, refugces, international students, and second-generation immigrants. (In this paper the term LEP will be used when citing information from documents of the State of California, as this is the term applicd by the Statc to ENNL students.)

Immigrants are students who arrive in this country often accompanied by a parent or family member. They usually have some educational background, al though the quality varies. The student probably had little, if any, input on the decision to emigrate and may have left family members behind. Some family stress is to be expected as the family members adjust to their new environment and attempt to find a place within the job market.

Refugees have fled their country, usually for political reasons. Often they have misgivings about leaving their homeland and hope to return if things change. Their arrival in this country may have been delayed several years by a stay in a refugec camp. These children often have little formal education, if they have any at all.

In California, these immigrants and refugees come mainly from five areas of the world (Olsen, 1988). The first area they come from is Mexico. Mexico borders California and more than one-third of the state's Mexican-heritage residents are immigrants. They are often from rural regions or small towns, and are often fleeing poverty.

A second area of origin for California immigrants is Central America. Like their Mexican counterparts, they too are seeking a better economic environment. Unlike their Mexican counterparts, many are refugees who have left Central America because of the violence or civil wars. The countries of origin for this group include El Salvador, Guatemala, Nicaragua, Honduras, and Belize. The majority of Central American immigrants and refugees arrive in the United States with few skills and little education.

The third area is Southeast Asia. Countries included in this group are Vietnam, Laos, and Cambodia. The early immigrants (pre-1980) from this part of the world were most often educated and came from a high socioeconomic background. This is no longer true of 
most of the current arrivals. These are of ten refugees who come from a farming or fishing background and have little or no formal education. Many have spent ycars in refugec camps before finally arriving in the United States.

The fourth area is the Philippines. The most recent immigrants include educated families who are joining relatives already in California or those who are secking a more stable economic and educational environment.

The fifth area of origin is the Far East. Included here are the countries of Korea, China, and Japan. As a group, these immigrants are educated, many arriving in California with college degrees. Today, the immigrants from this region are usually seeking improved educational or economic opportunities or to reunite with family member already here.

International students are individuals who have received a student visa and have come to this country to study. They are usually college age and are not attending $\mathrm{K}-12$ ' public schools. Therefore, this paper does not address this group.

The final group of LEP students are second-generation immigrants-those bom in this country, but whose family members speak a language other than English. In California, the largest group of second-generation immigrants are of Mexican descent. It is estimated that 10-25\% of monolingual, Spanish-speaking children are born in the U.S. (Olsen, 1988).

\section{Educating ENNL Students}

Though their backgrounds may vary greatly, all ENNL students arrive at the classroum door with a need to learn and master the English languagc. Current second language acquisition theory and research states that the best way to educate and teach these students is bilingually (Cummins, 1981; Hakuta, 1986). Cummins (1981) states that there is an underlying linguistic proficiency that transfers. In other words, literacy skills, math skills and others that children may have developed in their first language transfer to their 
second language. Content and comprehension should continuc to be taught in the primary language while the student begins to develop the second language. In this way, years of children's education are not "wasted" as they struggle to learn English. Cummins (1984) further states that second language learning can be viewed in two parts: BICS and CALP. BICS, Basic Interpersonal Communication Skills, is oral fluency in the language. The student can carry on a dialogue and make himself/herself understood by the teacher and other students. A student who has developed BICS can ask the teacher to be allowed to go to the bathroom, order his/her lunch, or even argue over a foul on the basketball court. In other words, a student possessing BICS has language proficiency in everyday communicative situations filled with context. That is, communication where the ENNL student can negotiate meaning from the feedback and the situational cues. This oral fluency, which takes about two years to develop, should not be confused with CALP, Cognitive Academic Language Proficiency. This cognitive language proficiency refers to the academic skills, reading comprehension, writing ability, higher order thinking skills, that students must develop in English to succeed in the academic environment. This is the language that is context reduced and cognitively demanding. It is the language required to write an essay or make a persuasive speech. There is little feedback or situational cues for the ENNL student to draw on in these situations. This proficiency takes from five to seven years to develop (Cummins, 1984).

Arguments for providing the ENNL student with a bilingual education are strong. The reality is that bilingual education is not always financially or numerically possible. In California, in the four-year period between the 1985-86 and 89-90 school years, the number of LEP students increased 52\%. In the 1990-91 school year, 986,462 LEP students were enrolled in California public schools and accounted for $20 \%$ of the school population (Olsen, 1991). Between them, LEP students spoke close to 100 different languages. The unfortunate reality is that it is not possible to provide all these students with 
a bilingual education. According to Olsen and Mullen in the exccutive summary of Embracing Diversity (1990), there are too few bilingual and specialist teachers to work with this increasing population. The result is that most ENNL students spend the majority of their school day in mainstream classrooms. As a consequence, most ENNL students find themselves in heterogeneous classrooms taught in English for English speaking students.

Krashen's second language acquisition theory states that students must receive comprehensible input to acquire a second language (1982). Comprehensiblc input is language that is near to the student's actual development or competence (referred to as $i$ ), but goes just beyond that point to include concepts and structures that the student needs to acquire (referred to as $i+1$ ). The meaning of what is being said is bcing used to acquire further language competence. Comprehensible input does not occur in every conversation between a native speaker and an ENNL student. This input must be relevant and interesting to the ENNL student. Comprchensible input combines the familiar with something new and includes key phrases and gestures. Krashen (1982) further states that the affective filter needs to be low. A low-affective filter occurs when students have high motivation and selfconfidence and low anxiety. A low-affective filter results in the student receiving a large amount of input and increases the likelihond that the student will interact with other speakers of the second language. Ellis, in his Variable Competence model (1986), believes that one must look beyond input to the interaction. The second language learner must be given the opportunity to negotiate meaning from and with language.

The responsibility of creating an environment in which the learning of a non-native language can occur falls to the classroom teacher. In addition to teaching English to nonnative speakers, the teacher must also teach the content of the curriculum, e.g., history, the scientific method, writing skills, literature. To accomplish both simultaneously often requires that the teacher utilize what are considered new or non-traditional approaches. 
Suggestions for these approaches include validating all students' backgrounds and expcriences, teaching integrated or theme-based lessons, or adopting a student-centered approach where students communicate with and learn from others (Olsen et al., 1990; Williams, 1992).

What a challenge today's California public school teacher faces. Constance Olivia Williams (1992) lists the following as key elements in the effective instruction of ENNL students who are in the mainstream classroom:

Instruction is delivered in context, with students actively engaged.

Instruction is student-centered so that students draw on their own background, knowledge, and experiences.

Theme-based instruction allows students to hear language and vocabulary repeatedly in multiple contexts while seeing that the disciplines are interrelated.

Instruction is communicatively-based where language is used to solve problems for a "real" purpose.

Instruction is holistic with students working on listening, speaking, reading, and writing simultaneously.

A low-anxiety environment must be established, so that students will take risks and experiment with language.

An environment must be established in which students are encouraged to interact with each other.

In Embracing Diversity (1990), Olsen and Mullen offer some additional core elements to consider when teaching in a diverse classroom. Among these are using students' experiences as a basis for lessons, emphasizing language development and communication by integrating speaking, writing, and listening, integrating the curriculum, and creating a student-centered classroom incorporating group work and interactive learning whereby students learn from each other.

One approach that utilizes many of the previously mentioned elements is cooperative learning $(\mathrm{CL})$. 


\section{Cooperative Learning}

$\mathrm{CL}$ is a group-centered process which encourages student growth in both academic and social skills. Students work together in teams toward common goals. The idea of students helping each other learn or working together cooperatively is not a new one. Colonel Francis Parker in the late 1800s and John Dewey in the 1930s were both strong advocates of students working together cooperatively. Educators have long believed that students could benefit from teaching or being taught by other students, although these cooperative learning strategies fell into disuse (Johnson, Johnson, \& Holubec, 1986). Recently, there has been a resurgence of support for CL. In its current incarnation, CL is more than just a strategy for students to work together in groups; it has become a philosophy (Johnson et al., 1986).

CL has five elements:

Positive interdependence. This is the students' perception that they will succeed or fail together as a team. It is accomplished through group goals and rewards. Team building and division of labor also help to build the positive interdependence among heterogeneous team members.

Face-to-face interactions. Students need to communicate about the task and the content with each other.

Individual accountability. Each member of the team is responsible for learning the material or a portion of the task. No one student can do all the work.

Interpersonal and small group skills. Students must be taught the necessary social skills needed for them to function as a team in a heterogeneous group.

Processing. Students analyze how the group is performing as a tcam and with regard to their required task.

(Johnson et al., 1986)

Spencer Kagan (1992) states that while CL practices vary greatly, there are six underlying concepts:

Teams. Ideally, a group of four students that have a strong, positive identity as a team, that accert each other, and provide mutual support. The tcams are heterogeneously grouped and endure for a period of time. 
Cooperative management. Teachers who use CL strategies need additional classroom management skills. These include classroom arrangement to facilitate team member's access to each other, noise level management, establishment of a quiet signal to focus all attention on the teacher, efficient materials distribution, and modeling of appropriate CL behaviors.

Will to cooperate. The will to cooperate must be created and maintained in a CL classroom. Three ways to do this are teambuilding, classbuilding, and the use of cooperative tasks and reward structures. Teambuilding and classbuilding are activities that help students get acquainted, form an identity, and learn how to be supportive of each other. Cooperative tasks are those where no one student can complete the task alone. Reward structures that help create a CL classroom are those based on team or class improvement.

Skill to cooperate. Students need to be taught, through modeling, reinforcement, role assignments, structuring, and reflection, the social skills necessary to function as a cooperative group. These skills include listening to each other, resolving conflicts, keeping on lask, setting and revising agendas, and encouraging each other.

Basic principles. The three fundamental principles of $\mathrm{CL}$ are simultaneous interaction, positive interdependence, and individual accountability. Simultaneous interaction is the idea that several students are engaged in active participation at the same time. (For positive interdependence and individual accountability refer to the five elements of CL by Johnson et al. on previous page.)

Structures. Each $\mathrm{CL}$ approach, and there are many, has a different emphasis. It is, therefore, important that teachers gain a knowledge of these different structures so that they may draw on the most appropriate structure for their learning objective.

Cooperative learning must be distinguished from traditional group learning. In CL

groups, all members share in the leadership responsibilities. Team members are expected to help all members achieve. The goals of the cooperative group are learning, and establishing and maintaining good working relationships among the group members. While students are engaged in CL groups, the teacher does not use this time to catch up on paperwork. Rather, the teacher observes the groups' progress and interaction and gives feedback to them. Time is given for the students to "process" how they are functioning as a group. Processing time and teacher feedback provide opportunities for the group to improve its effectiveness. 
Some examples that incorporate cssential components of CL follow:

Cooperative Projects (Group Investigation and Co-op Co-op)-Group members work together, each taking a rolc or part, to prociuce a group project or product. Usually there is no competition between groups.

Jigsaw-All groups are given the same task. This task could be learning the material in a social studies chapter. Each group member is responsible for part of the material. Members from cach group who are responsible for the same material meet together in expert groups. Once the material is mastered, experts retum to their original home group to present their material and help the group learn it. An individual test is given to all students on the material.

Learning Together-Students work in small heterogeneous groups to problem-solve. Their task may be as simple as a joint worksheet. The groups are praised and rewarded as a team.

Peer Practice (Student Teams Achievement Division and Tcams-GamesTournament)-Group members help each other practice the assigned content. The goal is to bring each student to his/her own highest level of achicvement. Rewards for teams are based on totaling improvement scores of the individual members.

(Jacob \& Mattson, 1987)

\section{Benefits of Cooperative Learning}

In the past decade, considerable research has been conducted on the effect of $\mathrm{CL}$ on student academic achievement, intergroup relations, self-esteem, and attitudes towards others. Most of the research on academic achievement shows that $\mathrm{CL}$ is effective in increasing student achievement (Cohen, 1990; Kagan, 1992; National Education Association [NEA], 1982). This increased student achievement includes non-white students (Gallien, 1988). Overall, the research has established that there is a positive effect from CL on academic achievement.

This does not mean that there is agreement as to the most effective CL method. Nor does the research clearly show whether high achievers or low achievers benefit most from $\mathrm{CL}$. Research has shown both groups benefit from CL. The evidence for which group benefits the most, according to the NEA (1982), seems to be about equally divided. Also, some research has suggested that academic achievement results are directly related to the 
quality of group interaction taking place (Solomon, Battistich, \& Delucchi, 1990). This research indicated that increasing the frequency of group interactions did not result in positive group outcomes unless the quality of the interaction (as rated by trained observers of student participants) was high. The researchers actually found that if the quality of the interaction was rated low, increased frequency led to poorer group outcomes (Solomon et al., 1990).

There is extensive research on the effect that CL has on intergroup relations. With few exceptions, this research shows that students who work together like each other, cven students from different ethnic backgrounds (Cohen, 1990; Kagan, 1992; NEA, 1982). According to the NEA document on CL (1982), when grouped together in CL groups, students from varying ethnic backgrounds have the opportunity to see each other as people instead of as a color: "Regardless of the ethnicities involved, the cooperative learning strategies apparently make it possible for students to see one another in a positive light and to form friendships based on human qualities rather than on skin colors or accents" (p. 24). Studies have documented that these new friendships formed within the CL groups carried over into the students' social lives outside the classroom (Ascher, 1986; NEA, 1982). Other studies (Conwell, Piel, \& Cobb 1988) found that students who have a chance to practice CL for problem-solving enjoy school more.

A third area of research concerning CL is its effect on students' self-esteem. Selfesteem is a person's own self-evaluation which expresses his or her notion of worthiness, capabilities, and significance. It is derived from personal experiences and interactions with others. High self-esteem is equated with students' ability and willingness to learn and take risks. Many studies have shown that self-esteem is increased among students who work as members of cooperative groups (Kagan, 1992). Carol Ascher (1986) states that the reason for this is twofold. First, students experience more success in their schoolwork when they 
work in cooperative teams than when they work individually. Second, they fecl "liked" by the other group members.

CL has been used successfully with handicapped students mainstreamed into the "regular" classroom (Yager, Johnson, Johnson, \& Snider, 1985). Research has been conducted to see if the previous positive results for student outcomes was transferable to cooperative groups made up of non-handicapped and handicapped students. Concerns had been raised that this type of grouping might actually have an adverse effect on the handicapped students' self-esteem due to the discrepancy between academic achievement among the group members and the possibility of rejection by the non-handicapped students (Yager et al., 1985). The opposite has been reported in research. The self-esteem of the handicapped students was increased, their feeling of isolation was decreased, and they increased their academic achievement (Yager et al., 1985). In addition, increased selfesteem and academic achievement was reported among the non-handicapped group members (Yager et al., 1985). Perhaps the most important implications of the research is that not only handicapped students benefit from the cross-handicapped grouping, but all students benefit.

\section{Cooperative Learning and the ENNL Student}

In the 1980's, researchers began to ask questions about the possible benefits of CL for the mainstreamed ENNL student. Could these positive outcomes from studies among English speakers of varying ethnic backgrounds and academic levels be translated to students learning English as a non-native language?

Although research is just beginning in this area of $\mathrm{CL}$, there are indications that it provides opportunities for the interaction necessary for second language acquisition (deAvila, 1987; Jacob et al., 1987; Meyers, 1993). Research further indicates a greater improvement in English proficiency when CL methods were used over traditional whole 
class methods (Bcjarano, 1987; Kagan, 1992). Group work for second language learners in context-based classes provides opportunities for students to increase the quantity of language practice, improve the quality of their talk, and have individualized instruction (Long \& Porter, 1985). When ENNL students participate in CL group work, they are involved in a positive, effective classroom environment which increases student motivation (Long \& Porter, 1985).

Margarita Caldcrón (1989) cites the following benefits for using CL with ENNL students in the mainstreamed classroom:

1. CL can be used with students of all ages.

2. CL can be used with students of all levels of language proficiency (preproduction, early production, speech emergence, oral fluency).

3. Students with diverse backgrounds are not placed at a disadvantage when it comes to reading, writing, communication and critical thinking.

4. Students (particularly those identified as Levels 4 and 5) fine-tunc their language skills and develop learning strategies for mastering content.

5. Older pre-literate students gain knowledge of the structure of the English language in a safe and non-threatening way. They also learn how ideas are expressed orally and in written form.

6. CL can be easily integrated with content area instruction, i.e., science, social studies, math, ctc.

7. CL can be used in bilingual instructional settings where students learn in two languages.

8. CL can be used in combination with ESL instructional strategies in elcmentary and secondary ESL classes.

9. $\mathrm{CL}$ is fundamental for "sheltered content" classes in secondary schools.

10. $\mathrm{CL}$ is an effective management tool as well as an instructional stratcgy for mainstreamed classrooms where bilingual programs are not possiblc.

11. CL helps LEP students develop a positive image of themselves and others, enhances positive ethnic relations, and curtails discipline problems. (p. 1) 
Calderón (1989) further states that CL strategies offer what Krashen (1982) referred to as the "natural approach." Language is integrated so the leamer receives experiences with speaking, listening, reading, and writing. During the processing (debrieling) portion of the CL lesson, all students have the opportunity to discuss how they learn and their individual thinking strategies (megacognitive strategies). Finally, CL utilizes other students as peer tutors for the second language student. Calderón states that utilizing CL creates an environment where ENNL students have a low-affective filter and receive comprehensible input:

LEP students feel less intimidated or threatened in this low-affective filter environment where there is comprehensible input and quality output on a continuous basis. In this setting more learning actually takes place when cooperative teams are well structured, there is no place for the student to hide, no way not to contribute. Everyone helps, everyone asks for help. (Calderón, 1989, p. 2)

According to Krashen (1982), low-affective filters and comprehensible input are essential if second language (or additional language) acquisition is going to take place.

This requirement to contribute raises an interesting question. Could CL create a debilitative anxiety level in some students that is detrimental to their learning? Or, does it create facilitative anxiety, some concern or apprehension over the task, which has been found to help the second language learner succeed (Brown, 1987).

Academic achievement is addressed in a few studies, but of ten in terms of all students, not just the ENNL student. The ENNL students are grouped together with the Englishspeaking students when the subject of academic achievement is addressed. According to Handscombe in When They Don't All Speak English (1989), impressive gains have been documented for all students in the areas of academic achievement within classrooms that are organized as CL centers.

The rescarch on CL and the ENNL student concentrates on language development and leaves some interesting questions: Does the quality of the interactions, as found in the 
Solomon, Ballistich, and Delucchi study (1990), effect the positive outcomes of the group? Do ENNL students contribute as full CL group members while they are developing the English language? Group interdependence, according to Johnson, Johnson, and Holubec (1986), is essential to CL. It is one of the components that distinguishes CL from small group learning. If group interdependence does not exist, will the ENNL student experience the increase in self-estecm that is a benefit of CL? What if ENNL students are unable to participate as full group members? Are they in danger of being rejected by their English speaking group counterparts as ineffective team members?

Cohen (1990) warns that status differences among group members can affect the level of student participation in the $\mathrm{CL}$ group and the amount of learning that takes place. She describes status as how students rank one another in the areas of academic abilities and personal popularity. Students with low status are seen as less competent. Low' status students often will not participate in the group work and sometimes become "behavior problems" (Cohen, 1990). Low status students may interact less with the group and therefore learn less than they might have had they had more interaction (Cohen, 1990). Is it possible that ENNL students could be viewed as low status members by other group members? Would being perceived as a low status member have an effect on the ENNL students' self-estcem?

These questions lead to the question this research was designed to investigatc: Do CL strategies have an effect on the ENNL students' self-cstecm?

\section{Summary}

The number of ENNL students in California public schools continues to rise. These students come from varying backgrounds but have at least two things in common: 1) the need to learn English to communicate with others (BICS), and 2) the need to leam English to succeed in the academic setting (CALP). Second language acquisition theory states there 
is a common underlying proficiency between the speaker's first language and the second language he or she is acquiring. If the student's education continues in the primary language while the second language is being acquired, knowledge and skills will be transferred. Ideally, bilingual education should be provided for all ENNL students. In reality, most ENNL students are placed in heterogeneous classrooms designed to teach content to English speakers. Teachers must modify instruction to meet the needs of the ENNL student. CL is offered as a method that will benefit both English speakers and ENNL students. Much research on CL has been done with English speakers and it has documented increases in academic achievement, positive intergroup relations, and selfesteem. Research on CL and ENNL students is just beginning. The research shows that $\mathrm{CL}$ helps develop English language proficiency. There are indications that CL may also enhance ENNL students' self-esteem and increase their academic achievement, although more research needs to be done in these areas. Since this is a relatively new area for research, there are still many unanswered questions about the ENNL student and CL. 


\section{Chapter Three \\ The Research Methodology}

\section{Introduction}

In order to answer the question about the effect of CL strategies on the self-estecm of ENNL students, I used a case study approach with three sixth-grade students in the science lab. Guided by the research question, this approach focused on the individual students in a natural school setting (Johnson, 1992; LeCompte and Goetz, 1982). This chapter is a discussion of the methodology used to collect the data that comprises the case studies. The chapter begins with a description of the setting where the research was conducted. The chapter continues with an introduction to the three students and reasons why they were selected. The chapter goes on to discuss the techniques used for data collection and analysis.

\section{Research Setting: The Science Lab}

This study took place in a suburban elementary school (grades K-6) which receives state and federal funding for school improvement and Chapter 1 students. About $40 \%$ of the school's 660 students qualify for Chapter 1 funding. The socio-economic status of the student body ranges from lower to middle class. Many receive free or reduced-cost lunches. The majority of the households have either two working parents or a single head of household who works.

The research took place in my classroom, the science lab. On alternate weeks in grade six, students receive daily science lessons in the science lab. The class period lasts forty minutes. For the purpose of this study, I focused on one sixth-grade class during the spring semester, from March to June. During this time we studied two units, Electricity and Magnetism, and Genetics and Family Life/Sex Education. The students sit at rectangular or 
square tables in CL teams of from four to six members. During the study, there were nine teams in the science lab.

Team building, an activity that is designed to bring the tcam together and give them an identity, is done after each team is formed. I use activities such as making a team banner to accomplish team building. The students in cach team choose a team name which is related to the subject area we will be studying. In addition, they must come up with four words that describe their team. The four words selected must convey things all tcam members have in common. These words, their team name, individual names, and an illustration must appear on their banner. They are given one class period to complete this task. The banners the teams produce are displayed in the room for the duration of the unit. The team names are placed on the Bonus Point chart for that class on a bulletin board that is titled "Cooperation Is Key." Bonus points are awarded for team work in the areas of homework, participation, and on-task behavior throughout the unit. At the end of the unit the two teams that earn the most bonus points receive a prize. The first place team gets to choose their prize, e.g., a homework pass for each team member, a popcorn and punch party for the tcam, or a prize from the prize box. The team must reach a group decision for which prize they will receive. (The sccond place team receives candy from the class candy jar.)

The three students that I studied were never on the same team during the period of this study. They were each members of two different teams during the project's duration. I selected the first set of teams. When I did so several wecks before the study bcgan, I made certain that the tcams were heterogencous. The teams were made up of both boys and girls, had members of varying ethnic backgrounds, and the members had different strengths. For example, one member might write well, another might have high verbal skills, another might draw well, and another might have good reasoning skills in the area of science.

Students selected their own teams for the second unit during this study. However, I set the following parameters for the students: the teams were to include both girls and boys, 
provide support for all members, provide a comfortable atmosphere for sex education, and could not include pairings that would result in trouble for either an individual member of the team or for the team as a whole. I reserved the right of final approval and the right to place a person in another group if an inappropriate choice had been made. I found that their choices usually worked out well.

The students participated in several different instructional strategies during this project. Students were involved in direct instruction lessons, whole group class discussions, audience participation object lessons ${ }^{1}$, and both $\mathrm{CL}$ group and CL pair work. Within the CL groups, they engaged in several labs. These labs included circuit building, magnet attraction, and genetic trait identification. Most often these labs required the students to share materials and discuss their observations. For example, each group of students had only enough materials to build one series circuit or one parallel circuit during the circuit building lab. They also designed an insulator/conductor tester which they subsequently built and used in a lab. Students normally completed their own lab reports, but occasionally the groups would work on a community lab report. In this casc, all group members received the same grade. In the CL groups, they also wrote and illustrated a group book entitled "Edgar the Electron." This was a fictional story about an clectron in a variety of settings that was based on science concepts learned during the electricity unit. Each group member had to participate in the making of the book.

There were also team discussions where groups would generate answers or lists that were shared with the whole class. Some of these discussions included making a list of secondary sex characteristics, defining the concept of "family," and sequencing a story about fertilization. Finally, there was one whole group performance test, administered by

\footnotetext{
${ }^{1}$ Audience participation object lessons are ones in which I use common objects to explain something abstract with the help of the students in the class. For example, to explain the flow of electrons in a circuit I use five student volunteers and six balls. They pass the balls from one hand to another to illustrate the jumping of an electron from one atom to another in a closed circuit.
} 
me, for which they received a single group grade. I asked the groups to build a closed circuit, a parallel circuit, or a series circuit. An individual group did not know which circuit they would be asked to build prior to the test, although they had built each of the circuits during cooperative group labs. I gave the materials to one of the team members to start the circuit and then rotated the materials around, having different group members build on what another member had begun. I then asked each group member an oral question relating to the circuit the group had constructed. Based on the circuit built and the ansivers given, a group grade was determined.

In addition to whole team cooperative group activities, there were also cooperative pair activities. Students chose their partncrs from within the cooperative teams and worked together on specific labs and on a multiple day quiz. During the quiz, the pairs drew a "baby monster" based on a gene pool they had been given. Students were given two days to complete this quiz. Pairs also worked together discussing and completing a few worksheets during the sex education unit. If a member of a pair was absent, a trio was formed for that day's activity.

Students worked individually on their homework, during a long end-of-unit exam, and while collecting tickets for oral participation in whole class discussions during this project. These tickets were used during the sex education unit to calculate the students' oral participation grades. I announced the number of tickets required to carn a particular letter grade near the end of the unit. I did this for two reasons. First, the number of tickets required for an A differed from ycar to year and class to class depending on how many opportunities students within the class had been given to earn them. Secondly, students tended to remain actively involved in the discussions until the time tickets were collected. They were also less likely to give away tickets to their friends who had not earned them. Sixth graders can be very generous with their "extra" tickets. In the past, they have given them to friends so that the friend could also cam an A grade. Students received tickets each 
time they participated in whole group class discussions, when they correctly answered review questions, or when they shared a worksheet response.

In the whole-class setting, I led discussions of lab observations, conclusions, and responses on the worksheets. I also taught several short direct-instruction lessons with the aid of charts, diagrams, storytelling, and simulations using student voluntecrs. Some of these lessons included following an ovum on its journey to the uterus, a story about Mendel the Monk (the "father" of genetics), and a simulation where students played dominant and recessive genes. Direct-instruction lessons were more common during the sex education unit because hands-on activities are much more limited. The class also watched two films during sex education.

\section{The Students}

This study focuses on three ENNL students in the intermediate elementary grades, Chandra, Minh, and David. Each student arrived in the United States approximately one and one-half years prior to the study and was placed in the fourth or fifth grade at that time. None of the students' primary language is English. Chandra is from India and his primary language is Gujarati. Minh is from Vietnam and her primary language is Victnamese. David is from the Philippines and his primary language is Itocano. During their first year here, they received a school support program of English language development through a pullout stratcgy. They received this support outside the regular classroom setting. The classes were taught by an instructional aide who received direction from the students' classroom teachers. Often the teachers had received some additional training in working with ENNL students. The aide was not bilingual in the students' primary language. In the second year, none of the students received pull-out instruction from the instructional aide in English language development. One student, David, was placed in a special education program for language arts and math in his second year. Instruction was in English. The vast majority of 
these students' time is and has been spent in a mainstream English self-contained classroom. All of the students come to the science lab as part of their regular class. The students have had me as their science instructor since they first came to this school.

\section{Selection of the Students for Study}

I used the following criteria in selecting the three students for this study:

1. All students would be classificd LEP (Limited English Proficient-the official state and district designation) based on their scores on the IDEA oral language proficiency lest. This was verified by reviewing their cumulative record files.

2. Students would have been in the U.S. for more than one year, allowing time for some cultural adjustment.

3. Students would be at a level in their English language development where they could make themselves and their wishes understood through verbal or through a combination of verbal and nonverbal communication.

4. Students would be able to understand verbal directions when given in English and accompanied by a demonstration.

5. The sample would include both male and female students.

6. All students would be in the same science class so the setting and experiences of the students could be as similar as possible.

With these criteria in mind, I selected three students to participatc as subjects in this study and received parental permission to include each of them. There was a fourth student in the class who fit most of the criteria. However, this student had advanced English skills and would probably have been reclassified as Fluent English Proficient had she been retested. She maintained high academic grades in all of her English-taught classes. She did not seem to meet the intent of the criteria, so she was not chosen as a study subject. The three selected students were from three different countries and cultures, and spoke three different primary languages. I wanted to limit the number of students so that I would be able to adequately interview, observe, and record audio samples of each student while continuing to perform my other teaching duties. 
These students are representative of the growing population of ENNL students in the intermediate elementary grades. They receive the majority of their English language and content instruction in a mainstream, heterogeneous classroom. They speak various primary languages and are not yet fluent in English. They have difficuity understanding academic concepts unless adaptations are made to the traditional ways of presenting content material. They are students who have begun to successfully communicate their desires and opinions through their non-native language, English. In other words, they are ENNL students who can normally express themselves effectively in helerogeneous CL groups. They may use more than just verbal communication. They may add gestures and other body language cues to convey meaning and their language may contain grammatical or meaning miscues. This sample represents ENNL students who have had the time and opportunity to adjust to American schools and experience various instructional strategies common here, including CL.

\section{Data Collection}

This project focuses on three children. The case studies of the three students are comprised of student interviews, information from the students' cumulative files, attitudinal surveys, audio tapes, field notes, and video tapes (Johnson, 1992; LeCompte and Goetz, 1982).

\section{Interviews}

At the beginning of this project I interviewed each of the students for background information. The purpose of these interviews was to learn more about my students' origins, primary languages, home lives, and prior school experiences. Included in the interviews were questions such as, "Where were you born?" and "Did you go to school there?" 
In this first interview, I also wanted to know how the students felt about their current school experience and working in cooperative groups. I wanted to establish whether there were any strong feelings that might influence their experiences during the study before I began to tape and observe them. Questions in this part of the interview included, "What is your favorite (and least favorite) subject in school?" "Why?" and "How do you feel about working in cooperative groups?" In addition to questions on cooperative groups, I asked the students to rate their preference for certain instructional strategies (including cooperative group, teacher-directed, and self-directed) using a six-point scale. The students were also asked to rate the same strategies in terms of which strategy helped them learn most effectively. A rating of 1 was considered the highest, indicating the subject's most preferred instructional strategy and the most effective instructional strategy for leaming. When I administered the survey, I gave an example of each instructional strategy that was related to experiences ENNL students had in the science lab. This served to clarify the meaning.

A final purpose of this interview was to begin a new relationship with the students. I wanted them to relax about the research process and realize that they could be honest with me without worrying about how it might affect our relationship as teacher and student. After the interview questions were completed, I explained what I would be doing, what they would be doing, and that no one would ever know who they were except for me because their names would be changed in the research report.

The students were also interviewed halfway through the study, after the first two attitudinal surveys were administered, and at the end of the research, after the final two attitudinal surveys. One of the purposes of these interviews was to discuss the survey answers given by the students. I asked them to explain why they had given the particular responses they did. In the final interview, I also asked them to compare the expericnces 
they had in their first CL group to those in their second CL group. The interviews were conducted individually and all were audio taped.

\section{School Cumulative Files}

I obtained additional background information through the students' cumulative files, e.g., responses from the home language survey forms and oral proficiency test scores. I also had access to the students' report cards and comments from previous teachers.

\section{Attitudinal Surveys}

I administered four attitudinal surveys following cooperative group activities or whole class activities to determine the students' self-esteem. Two of these surveys were given during the Electricity/Magnetism unit, during the first team placement. The first survey followed a group lab where students built circuits as a team and each completed a lab sheet. The next survey was given after the writing of a group book. Two other surveys were administered during the Family Life/Sex Education unit within the second team placement. The third survey came after a whole class discussion and the fourth af ter a cooperative pairs activity where students completed a worksheet together. I gave each survey after a different type of activity and an equal number for each group placement. This was to obtain a more balanced view of the students' self-esteem in different situations.

The survey questions (appendix A) were patterned after those Conwell, Piel, and Cobb (1988) used to measure the effect of CL on the self-esteem of native English spcakers. The survey was piloted in November and December 1992 by administering it to all members of the sixth-grade science class. This class included native English speakers, ENNL students who were now fluent in English, and ENNL students.

The surveys were given to all students in the class since it was administered during regular class time. However, only the surveys of the ENNL students were considered in this project. All questions on the surveys were utilized in data analysis for the ENNL 
students. The survey form was explained twice, in detail, to the whole class, with cxamples for each statement and response during the pilot. All students were familiar with it when the study began.

In the surveys, students were asked to gauge their contribution as a team member, rate their self-esteem level, and rate their enjoyment level following the activity. They were asked to relate their feelings about school following the activity. They were also asked about the level of pressure they had felt while participating in the activity. This last question was my own and was not included in the Conwell, Piel, and Cobb (1988) research. I included the question to investigate whether the level of stress was a debilitating one that affected the level of the student's self-esteem.

\section{Audio Tapes}

I audio taped the three students over a three month period from March to June. The taping actually took place for six weeks since the students come to science class cvery other week. One student was taped for thirty-five minutes each class period. The recorder was rotated from day to day among all the participants. Taping was not done on inservice days, on days when I had a substitute teacher, or on days when the students were taking exams. There were also three days when taping did not take place due to technical difficulties or student interference with the recorder. If a designated student was absent, another student was taped in his/her place and the absentee was taped upon his/her return. The tape recorder was turned on at the beginning of the period and the student's communication was taped while in the cooperative team groups, pair cooperative groups, and during wholeclass discussions. The ENNL students were not individually wired. The tape recorder was placed on the table at which the student was working and the microphone placed nearest the

ENNL student. The recorder picked up all group conversation and produced a good quality 
recording which could be transcribed in almost all cases. I collected five samples each of Minh and Chandra and six samples of David.

\section{Field Notes}

I kept field notes on lessons taught and student behavior during the lessons. Notes were made of student involvement in group activity or class discussion. It was not always possible to keep field notes for each lesson. For example, I did not keep notes during direct instruction lessons because I was unable to observe the ENNL students separately from the class as a whole. I also had difficulty keeping notes during certain lab activities where the observation process was interrupted by the need to act as teacher/facilitator for the students.

\section{Video tapes}

The instructional aide videotaped the students on three separate occasions. This helped me visualize what was happening in the cooperative group settings and allowed me a closer look at the type and level of participation of the ENNL student in the CL group. Two of the tapes were made during the Family Life/Sex Education unit when I was involved in more whole-class discussions, direct instruction, and helping student groups. In other words, I spent more time in the role of teacher and had less time for researcher observations. The videotaping allowed me to observe the students at a later time.

\section{Data Analysis}

The individual student case studies were developed from a compilation of the data collected. The data were examined for meaningful patterns (Johnson, 1992).

The analysis of the data occurred in two stages. The first analysis, involving the audio tapes, field notes, and videotapes, was designed to construct a "picture" of the level of the ENNL students' involvement within each of their group placements and what each ENNL student was doing within the group during the various activities. The second part of the 
analysis involved the attitudinal surveys. The purpose of this analysis was to look for any relationships between self-esteem and CL for the ENNL students.

\section{Data Analysis: Part One, Audio Tape and Observations}

The audio tapes were transcribed. First, these conversations between the ENNL students and other group members were read. This gave an indication as to how the other CL group members were treating the ENNL students. Then, the ENNL students' utterances were coded (LeCompte and Goetz, 1982; Charles, 1988). The utterances were coded as either a question, an answer to a question, or a statement. Questions were requests for information, materials or clarification. An example of a question would be, "Can I have a pencil?" An answer was a response to a question asked by either a group member or the teacher. Statements were neither questions to, nor responses to questions from either the teacher or a group member. For example, during the circuit lab, Chandra advised the team members that they had incorrectly completed a portion of the lab write up with the statement, "Oh, no you don't do that. You draw a circuit of your own that you think could." In this particular occurrence, the statement was directed at the group as a whole. At other times statements may have been directed to an individual or to no one in particular.

This coding of utterances gave me insight into what the ENNL student was doing within the group. It also gave me an indication of whether the ENNL student was making an effort to involve him/herself within the CL group and whether the other group members were making an effort to involve the ENNL student. Each utterance was further classified into one of four classes. These four classes I developed helped me determine whether the students' utterances conveyed scientific understanding, were related to the science activity, or not related to science in any way. 


\section{Class One Utterances: Activity-related}

A class onc: activity-related communication consisted of any communication related to what was happening within the science classroom, but one that did not reflect understanding of the unit's science concepts. Into this classification fell the following:

a) questions asking for supplies or information to complete the task at hand, c.g., "Where does the light bulb go?"

b) requests for clarification or responses given to clarify, e.g., "What was the answer to number two?" "The teacher said the answer is true."

c) mere repetition of content material provided from either the teacher or a group member, e.g., "She said we need wires for this circuit."

d) statements about students' feelings regarding the task or preferences on which rolc within the group they wished to perform in order to complete the given task, e.g., "Building circuits is fun." "I want to be the materials getter loday."

e) reading directions aloud or paraphrasing verbal directions given by the teacher, e.g., "She said to read the whole lab first, then to start."

f) communications necessary to functioning within the science classroom but not reflecting the science concepts being taught, e.g., "You forgot to give me a ticket for my answer."

\section{Class Two Utterances: Reflecting Conceptual Understanding}

Class two: reflecting conceptual understanding communications consisted of any communication that reflected some understanding of the science content and concepts being taught. Communications falling into this classification included the following:

a) answers to questions that required content knowledge and/or understanding, e.g., "The ovum leaves the ovary during ovulation."

b) questions about content that reflected some understanding of material. These are not requests for simple clarification of an answer, e.g., "Are Christmas lights a series circuit since when one goes out they all go out?"

c) suggestions or statements within the course of a lab that reflect processing and/or understanding of the material, e.g., "To make this into an open circuit we need to disconnect one of the wires connected to the battery." 


\section{Class Three Utterances: Unrelated to the Activity}

Class three: unrelated to the activity communications were those that were not related to the classroom task or the science content. This classification consisted of the following:

a) any communication about the social life of the individual, c.g., " $M y$ girlfriend bought me a present."

b) any comment on current events not related to content, e.g., "Did you see the news about the boy who was murdered in San Jose?"

c) any comments about the tape recorder used to collect data, c.g., "Don't touch that button!"

d) any derogatory remarks or name calling regarding other group members, e.g., "You're stupid."

\section{Class Four Utterances: Insufficient to Code}

Class four communications: insufficient to code were any that were too limited to be classified. Into this classification fell the following:

a) statements, responses, or questions where a large portion of the communication was inaudible and therefore the meaning was not clear.

b) any statement, response, or question where the context could not be established and therefore the meaning was not clear.

Tables were prepared using these four classifications. Again, these classes gave me insight into what the ENNL student was doing in the group. Was he/she helping with the task? Was he/she contributing to the science learning in the group? Did his/her utterances reflect an understanding of the science concepts being taught? Looking at a combination of the conversations between the ENNL student and the other group members and the two types of utterance coding, I was able to get an idea of what role the ENNL student played within the group and whether he/she functioned as a full and valued team member.

Finally, communications were labeled as being within the cooperative group or within the wholc class structure. This gave me some insight into student involvement levels while in whole-class groupings and in CL groupings. These data were compared with my teacher 
observations and video tapes for further information on the type and purpose of the students' uttcrances as well as their role within the group.

\section{Data Analysis: Part Two, Attitudinal Surveys}

The responses of each student on their four surveys (sce Appendix A) were tabulated for each of the two placements and then examined. For example, how many times did the students respond to question one (How do you rate your work in this activity?) with a rating of "high" in the first group placement? In the second placement? How many times did he/she rate their work "medium" in each placement? How many "low" ratings were there in each placement?

In addition to examining the students' responses to each individual question, the questions were put into four groups. Similar questions were grouped to further establish any relationship between the student's self-esteem and CL strategies as follows:

1) Questions relating to the students' perceptions of the level of work and involvement during the task. \#1 How do you rate your work in this activity? \#7 How do you rate your part in helping your group solve the problem? \#8a Who helped the most within the group? $\# 8 b$ Who helped the least?

2) Questions relating to feelings about the task.

\#3 Did you enjoy today's activity?

\#5 Rate the amount of pressure you felt to participate in today's activity.

3) Questions related to their self-perception of personal worth and selfconfidence.

\#2 How did working on today's activity make you feel about yourself?

\#6 After today's activity I felt...

\#7 How do you rate your part in helping your group solve the problem?

4) Questions related to their overall feelings about school.

\#4 How much do you like school after working on activities like the one you participated in today? 


\section{Chapter Four \\ Chandra, Minh, and David: \\ Three Case Studies}

\section{Introduction}

In this chapter, case studies of each of the three students are presented. Each student was a member of two different $\mathrm{CL}$ groups. The data for each placement are presented separately. As I examined the data, it was clear that group placement influenced both the level of group involvement and how the students felt about themselves. The students' utterances, attitudinal surveys, and interviews are presented for each of the group placements. The group placements for each student are then compared. Finally, the relationship between the data and the original question is explored. It should be noted that the term "LEP" is used in these case studies when this was the designation given by the school.

\section{First Case Study: Chandra \\ Background}

Chandra is an eleven year-old, sixth-grade Indian boy. He arrived in this country in late August of 1990 and entered the fourth grade. He is an only child. Chandra's primary language is Gujarati. He was classified as LEP upon his enrollment in elementary school here in the U.S., even though he had received English language instruction in his school in India. This may account for why he does well orally but struggles a little when asked to communicate in writing. It takes him a long time to put any thoughts on paper. The written work I have received from him is brief and, like many ENNL students' writing, does not show written fluency in English. Chandra is a tall, quiet, and very polite young man. His favorite school subject is social studies because he enjoys learning about the past through reading the textbook. He says he also enjoys learning through science textbooks which are 
not often used in my classroom. His least favorite subject is writing because it is hard for him to come up with ideas and then write them down. He indicates that he likes working in cooperative groups. When I asked him to choosc his ideal team members, he chose two boys. When asked why he chose these two, he responded that it was because they would be nice to him and help him if he needed it.

First Group Placement: Findings From Audio Tapes, Field Notes, and

\section{Video Tapes.}

Chandra's first group was made up of three girls, two boys, and himself. The group had separated itself, with the three girls sitting at one end of the rectangular table and the three boys sitting at the other end. Chandra was often uninvolved in the group activity in his first group placement. At times, he was physically excluded. I observed this on the video tape and noted it in my field notes. The group members sometimes turned their backs to him, actually blocking his view of what they were working on. When this occurred, Chandra did not attempt to move so he could include himself in the activity or the conversation. Sometimes he would work on the assignment by himself. At other times, he used class time to work on a homework assignment. Sometimes he would just sit there.

In this first placement, Chandra made some attempts to involve himself in the activity with other group members. The method he most often chose to utilize for this purpose was to make a statement to one or more of the group members, rather than ask a question. Of the 27 recorded utterances in this first placement, 67\% were statements (see Table 1). 
Table 1

Types of Utterances: Chandra's First Group Placement

\begin{tabular}{ccc}
\hline Type of Utterance & \# of Utterances & \% of total \\
\hline Questions & 3 & $11 \%$ \\
Answers & 6 & $22 \%$ \\
Statements & 18 & $67 \%$ \\
& 27 & $100 \%$ \\
\hline
\end{tabular}

Chandra's utterances indicated that he had an understanding of the science concepts during the magnetism and electricity unit. Forty-four percent of these utterances conveyed scientific knowledge or understanding (see Table 2). He would try and share his science

Table 2

Class of Utterances: Chandra's First Group Placement

\begin{tabular}{lcc}
\hline \multicolumn{1}{c}{ Class of Utterances } & \# of Utterances & $\%$ of total \\
\hline $\begin{array}{l}\text { 1. Activity Related } \\
\text { 2. Reflecting Conceptual }\end{array}$ & 14 & $52 \%$ \\
$\quad$ Understanding & 12 & $44 \%$ \\
3. Unrelated to Activity & 0 & $0 \%$ \\
4. Insufficient to Code & 1 & $4 \%$ \\
$\quad$ Totals & 27 & $100 \%$ \\
\hline
\end{tabular}

knowledge with his group. The group was not very receptive to Chandra's attempts, perhaps due to the manner in which he made these altempts. It sometimes sounded as if he thought he knew more than the other members and he wanted them to realize this so he could be included as a full-status group member. For example, during a multiple-day circuit construction lab, Chandra attempted to point out to the group his ability to do the lab work on two occasions. On the first occasion, he said the following: 
Chandra: What are you still doing? I'm already done with the circuit. Sec this wire. Sec what I showed. This goes from the bottom like that. Right here on the light bulb. The light bulb is right here, the load.

One of the boys in the group, Jason, responded, "We already did that," which ended the conversation and Chandra's attempt at group involvement. Later in the same lab, Chandra again interrupted and tried to point out to his team members that they had incorrectly completed a portion of the lab sheet. He again began with a statement:

Chandra: Oh, you don't do that. You draw' a circuit of your own, that you think could

Jason: What do you think we're doing?

Chandra: He's drawing that.

Ned: $\quad$ (laughing) I don't know.

Again, the conversation was short with the team members interacting only briefly. It is interesting to note that Chandra was correct when he pointed out that the team was doing this portion of the lab incorrectly. It is also important to note that the team did not change what they were doing after Chandra's statement, suggesting that Chandra's contributions were not valued by his group.

As previously stated, Chandra's attempts to participate in the group usually began with a statement. He did, however, ask questions $11 \%$ of the time. These questions referred to the assignment, e.g., "OK, so what do we write?" It is interesting to note that, although a group member would respond to these questions, the responses were very brief and did not lead to further conversation.

In addition to physically excluding Chandra, the group also failed to invite him to participate verbally. During the recorded conversations the group never asked him for information on the science material or for his opinion. His team members did not even ask him for a pencil. These were, however, parts of normal group conversation among the other group members. 
Although the group did nothing to encourage or invite Chandra's involvement, they were, nonctheless, unhappy when he was not participating or helping the group accomplish its goal. This became apparent in a conversation which began with Chandra making a statement about his homework addressed to no one in particular.

Chandra: (reading from his homework sheet) It's stuck in someone's hair and can't find its way out. A while trying to get out, trying to get out. The only lights

Jason: Hey, guys. Listen to this. He said stuck in someone's hair and he's trying to get out and[inaudible].

Ned: $\quad$ For static homework.

Leslie: You're not suppose to do your homework yet.

Ned:

Leslie: You're suppose to be helping us.

So? He did.

Ned: I know, Chandra.

Pam and

Shirley: Yeah, Chandra.

In conversations with Chandra, I discovered that he wanted to be involved in the science activities in his group. These conversations were of two different types. The first was in my capacity as the science teacher during class time. These conversations were about the science activities or concepts being discussed at that time in the class. The second type were the conversations we had during the interviews.

The teacher-student conversations demonstrated that Chandra did have some understanding of the science concepts being taught and a desire to share his understanding. Two examples of this type of conversation appear here. In the first conversation, I was addressing the group as a whole as they were having some difficulty constructing an electromagnet. Initially, one of the female members of the group responds incorrectly to my questioning. Before I could restate the question, Chandra jumps into the conversation. The conversation began when I (MD) asked the group what they needed to get the electrons to flow and make electricity.

Shirley: A pathway.

$\mathrm{MD}$ : A pathway. And a pathway is another name for?

Shirley: A holc.

Chandra: No, current electricity. 
MD: $\quad$ You've got to have current electricity. You've got to have a circuit to have current electricity to flow through. This (referring to their attempt at an electromagnet) does not current elcctricity makc. Why not?

Chandra: Because it does have an end to end.

MD: $\quad$ Right. Where should it go?

Chandra: It should go on the nail.

MD: Goes on the nail. Now, figure out where the nail goes.

Chandra had a good understanding of the science concepts in this unit. His

conversation with me demonstrated this. Yet, his CL group never turned to him and asked him for help even after demonstrations of understanding such as this.

Another of these conversations with me occurred during a whole class discussion, in which Chandra participated while a member of this group. He volunteered during one discussion on electromagnets.

MD: $\quad$ How are we going to know if we made a magnet or not?

Chandra: After a while take the nail out and put it near something that is iron or steel and it will attract.

MD: $\quad$ That would be one way. What, do you think it is making a magnet while the electricity is flowing through it?

Chandra: Yeah.

MD: $\quad$ How could we test it while electricity is flowing through it?

Chandra: We could just take some things made of steel and try it then.

MD: $\quad$ Good. OK and I want you to try both, Chandra. See if the, the, the, nail does stay a magnet afterwards and what happens.

Chandra did check it out. While the group was looking for their journals to note their electromagnet results, Chandra took that opportunity to try out his experiment with the nail.

Chandra responded to all my questions in these conversations and I was the one that ended them, not Chandra. His voice indicated an eagemess, rather than a rcluctance, to participate.

There was one other interesting observation I made regarding Chandra in his first group placement. The group had a tendency to talk when I was giving directions or tcaching a direct instruction lesson. Chandra rarely engaged in talking with his group or to himself aloud while I was talking to the whole class. Once again, he was not a part of this group. 


\section{Findings From Attitudinal Surveys and Interviews.}

While working in this group Chandra completed his first two attitudinal surveys. The first survey was given af ter a cooperative group lab on circuits. In this first activity, the group members were to build the circuits together, run a series of tests on them, discuss the results and then each complete a lab sheet individually. The lab sheet would be turned in for a letter grade. The second was given after the group wrote and illustrated a book on electrons and electricity. During the second activity, the group members worked together to produce one graded project-the book. After both activities, Chandra rated his work as low and his part in helping the group solve the problem as unimportant. He also rated himsclf as the member that helped the least. I asked him about his ratings of low and unimportant regarding his work. He replied:

Chandra: Because, usually, I don't get to do a lot of work when working on groups. Bccause they don't need me a lot. They do the work by themselves.

I asked Chandra why he thought this was and was there something he could do to get more involved in his group.

Chandra: I'm not sure. [I could] work more.

MD: What do you mean by work more?

Chandra: Think things up to help the group.

Chandra could offer no other suggestions for ways he could get more involved in the group. He had a little more to say when I asked him if there were things the group could do to help him "work more."

Chandra: They could let me get involved in things. They could help me out.

MD: $\quad$ Can you give me an example of how they could help you out?

Chandra: Like sometimes so the...ah...work like when we do the sheet...like when we do the lab and then ...ah....writc about it. Then, maybe, we could help each other out and write better and get a better grade.

MD: OK. Do you mean copy each other's work or talk about it?

Chandra: No, help. Talk about it. 
When asked, Chandra did not feel language, learning English, was interfering with his group participation. He did not feel language was a problem.

Chandra's surveys indicated that he felt both the circuit lab and the bookmaking were okay. In his interview, he indicated that he felt the activities and group work were okay. He would have preferred to learn the material through a science book, though. It was during this science book versus group work discussion that Chandra revealed (and surprised himself with the admission) that in groups he fools around. Having observed Chandra in CL groups prior to this research project, I believe he was indicating that he sometimes jokes with the male group members and sometimes does work other than the current assignment during class time.

Chandra had indicated on the first attitudinal survey, after the circuit lab, that he felt about the same about himself. On the second survey, after the book activity, he indicated he felt worse about himself. I asked him what it was about the activity or experience that made him feel worse.

Chandra: They don't let me work in groups.

MD: $\quad$ OK. You feel that your group members are keeping you from doing the work?

Chandra: Umhuh

MD: Is it ever because you just don't get involved or is it that you feel they don't let you get involved?

Chandra: They don't let me get involved.

MD: $\quad$ OK. If they don't let you get involved...like we've just moved into groups. Do you think in this group you will feel the same or do you think you will feel differently?

Chandra: Differently.

MD: Why do you think you're going to feel differently?

Chandra: Because now they, they let me help work in groups. They're nicer.

MD: $\quad$ OK. How do you mean nicer? What do you mean by nicer?

Chandra: Like they work with me and they let me get into the work.

\section{Summary of Chandra's First Group Experience.}

Chandra was of ten uninvolved in the CL group activity both physically and verbally. His attempts to become involved with his group usually began with a statement rather than 
with a question. Many times these statements reflected knowledge of the scientific concepts bcing taught. On more than one occasion, he tried to share this knowledge with group members. The group members usually made brief responses that would climinate further communication with or from Chandra. It was interesting to note that while the group did nothing to involve Chandra, sometimes even excluding him, they indicated to him that he should be helping the group. Chandra did not feel very good about himself or his work while with this group. His self-esteem was lower while in this group than it was in his second group placement.

\section{Chandra's Second Group Placement: Findings From Audio Tapes, Field} Notes, and Video Tapes.

The make-up of Chandra's second group placement was similar to the first group. Again it had six members, three boys including Chandra, and three girls. The second group placement was the one that the students chose for themselves. One of the boys Chandra chose to work with was Ned. Ned was a special education student that had been in Chandra's previous group.

The majority of Chandra's utterances in this group were again statements. Of 41 utterances, 25 (or 61\%) were statements (see Table 3; The increase in the number of utterances in the second group placement was due to the fact that there were more audio tapes for the second placement). The members, both boys and girls responded to some of Chandra's statements. Once again, Chandra's statements were about the science activity, sex cducation in this case. 
Table 3

Types of Utterances: Chandra's Second Group Placement

\begin{tabular}{|c|c|c|}
\hline Type of Uttcrance & \# of Utterances & To of total \\
\hline Questions & 5 & $12 \%$ \\
\hline Answers & 11 & $27 \%$ \\
\hline Statements & 25 & $61 \%$ \\
\hline Totals & 41 & $100 \%$ \\
\hline
\end{tabular}

Of the 41 utterances, $56 \%$ were activity-related and $37 \%$ reflected science concept understanding (see Table 4). Below are two examples of Chandra's statements and the responses from the group.

Table 4

Class of Utterances: Chandra's Second Group Placement

\begin{tabular}{lcc}
\hline \multicolumn{1}{c}{ Class of Utterances } & \# of Utterances & \% of total \\
\hline $\begin{array}{l}\text { 1. Activity Related } \\
\text { 2. Rcflecting Conceptual }\end{array}$ & 23 & $56 \%$ \\
$\quad$ Understanding & 15 & $37 \%$ \\
3. Unrelated to Activity & 2 & $5 \%$ \\
4. Insufficient to Code & 1 & $2 \%$ \\
$\quad$ Totals & 41 & $100 \%$ \\
\hline
\end{tabular}

In the first example, the students had been completing anatomy charts of the male and femalc reproductive systems. The group members were repeating parts of the systems and wondering aloud if they would have a test on this material. Chandra interjected his comment into the conversation,

Chandra: I never heard of these. Some of them I did. Edith: I never heard of the fallopian tubes or the cervix.

Chandra: And bladder. I know the bladder. [inaudible]. 
Ned: $\quad$ Penis. Definitely the penis.

In the sccond cxample, Chandra's statements reflect an understanding of the science concept being taught. The group was composing a list of secondary sex characteristics of males and females. Chandra actively participated in this activity.

Chandra: Penis. Penis hair.

Ned: $\quad$ Peanut.

Ron: Hairy penis.

Chandra: Just put body hair. They have a penis when they're born.

Ned or

Ron: $\quad$ Yeah, but its not hairy. (These two go on to say pubic hair several times. While they are doing this, Chandra continues with the activity.)

Chandra: Voice changes. Put voice changes.

In both cases, not only did this group respond to Chandra's utlerances, but they accepted them and included them in the group work.

This group did more than just respond to Chandra's statements; they asked him questions. In the first group placement, $22 \%$ of Chandra's utterances were answers to questions. These questions had all come from me. In his second placement $27 \%$ of his utterances were responses to questions. Of the 11 questions he responded to, 5 were asked by me. The remaining 6 were questions from his group (see Tables 1 and 3). Ned, in particular, would ask Chandra for verification of responses on the sex education worksheets. Ned was a special education student who Chandra spent a lot of time helping. Chandra was patient with Ned and treated Ned as a full group member. Below are two examples of this.

$\begin{array}{ll}\text { Ned: } & \text { Is it a B or D? } \\ \text { Chandra: } & \text { It's a B. Four is D. Five is B. }\end{array}$

Another example:

Ned: What number is it?

Chandra: It's number 13.

At one point Pam asked a question that expressed interest in what Chandra had chosen to do for his science project. 
Pam: $\quad$ You're going to bring what?

Chandra: A car, the challenge.

This question is an illustration of a major difference between the first and second placement. In this second group placement, Chandra was considered a full group member. Here, there was an interest in him and his choices that went beyond the current activity.

Chandra also continued to contribute during whole class discussions. He participated in this setting more frequently than he did during the time with his first group. This was due in part to an increase in opportunities to participate in this setting. One change I noticed during the time Chandra was with the second group was that even when he responded incorrectly in front of the entire class, his hand would go up again, volunteering to respond to the next question. This was not a behavior I had witnessed before. If he responded incorrectly, I usually did not see his hand up again for several minutes.

Chandra did two things with this group for which there was no evidence in his first group-laugh and argue. On the tapes with the second group, Chandra is heard laughing at things said in the large group. He also is heard joking. The tape player was set up at the CL group's table. It did, however, pick up the whole group discussions when the small group was not talking. My voice really carried and the tape of ten recorded me. In one instance, I was asking what a sperm would need to swim. I received answers from around the room: flippers, water, fins, towels, water. Chandra chimed in with life jacket. On another occasion, I was discussing what a child knows how to do when it is born.

MD: You didn't really make sounds other than cries.

Chandra: (to his group only) Yes you did.

MD: $\quad$ You learned

Chandra: (making baby sounds) Da Da...oh

Evidence of arguing was seen on two separate occasions. The first was over the spelling of the word penis.

Ron: $\quad$ How do you spell penis?

MD: $\quad$ Spelling doesn't count so just spell it so you know what it is.

Chrisy: $\quad$ P-e-n-i-s. 
Chandra: No, u-s.

Chrisy: i-s.

Chandra: u-s.

The other occasion was when I accidentally gave the group one too few handouts.

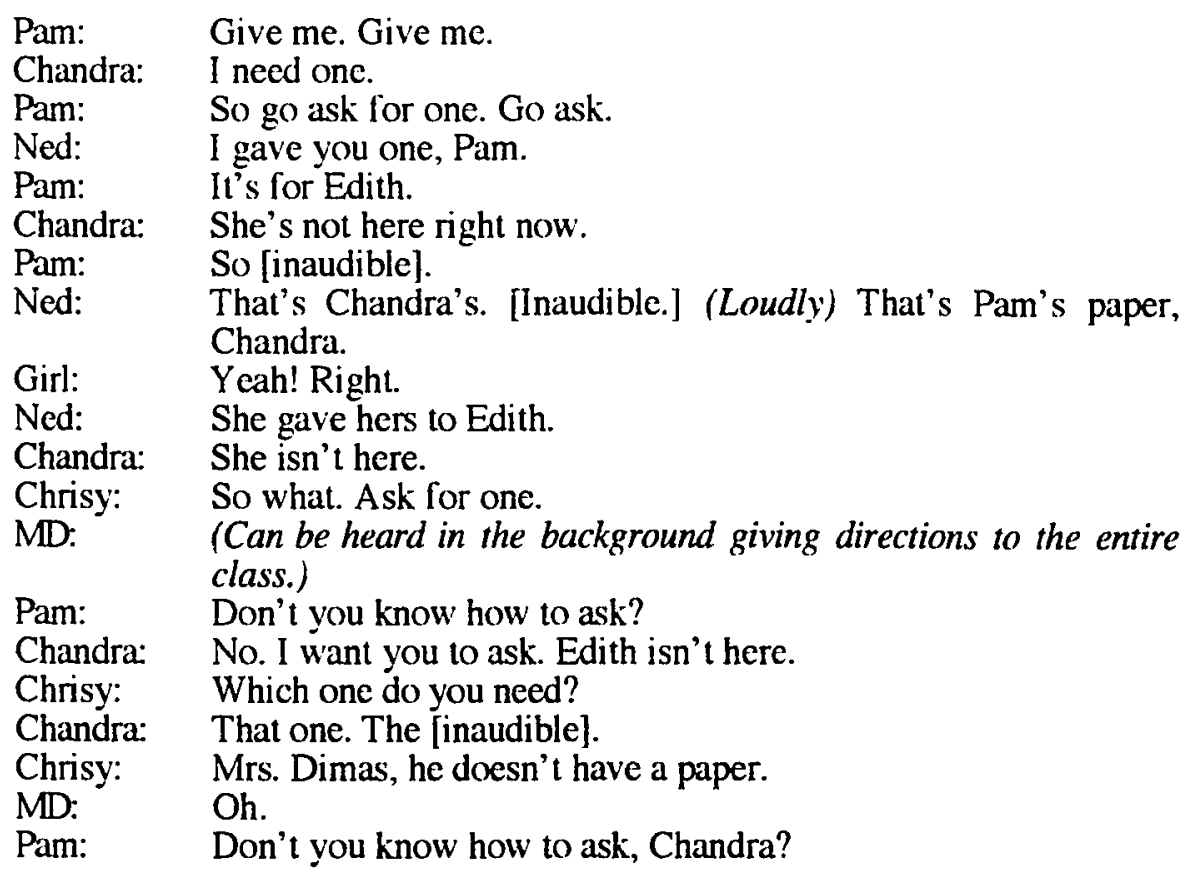

In this second group placement, Chandra stood up for himself when he felt that the group was treating him unfairly.

\section{Findings From Attitudinal Surveys and Interviews.}

Chandra's attitudinal surveys revealed a change in his self-perception while with his second group. The first of the two surveys was given following a whole class discussion of a worksheet which took the large part of the science period. This large group discussion was preceded by a short cooperative group period to prepare for the discussion. The second was given after a cooperative partner sequencing activity. Chandra rated his work as high and medium on these surveys. In his previous group, he had told me he felt no pressure because he wasn't involved. On these two surveys, he indicated that he felt some and a lot of pressure during the activities. Chandra rated his role as important. His level of 
activity enjoyment was also up. He indicated he enjoyed both these activitics very much.

Chandra's feelings about himself were positive. He indicated on one survey that he felt the same about himself after the activity and on the other survey he indicated he felt better about himself. His open-ended remarks about the way he felt were "good" and "better."

In his final interview, I asked Chandra to tell me which type of activity was his favorite. I asked him to chose between whole class, team-group, or partner activities. While he said he learned more in the partner or pair activities, the team was his favorite and the activity during which he communicates the most. He said, "[You] talked to everyone in the group and got answers. You shared answers." I asked him which cooperative group in science this year had been his favorite. He indicated the group he had prior to the beginning of the study was good, but the best was his current group. I asked him why this was his best group.

Chandra: Because we all do work and no one is left out and you all get to do work.

MD: Does working together as a group affect the way you feel about yourselr?

Chandra: It makes me feel better because I got to do the work.

MD: $\quad$ So it can make you feel better about yourself. Can it make you feel worse?

Chandra: I don't think so.

$\mathrm{MD}$ : So even though, before in other groups, when you were in the other groups, you said [on the surveys] that it makes you feel not as good about yourself.

Chandra: Yeah, before I got this group I didn't feel good. But before the group let my, before the group [that] didn't feel good...before that I was with Edward and David and I felt better. (Chandra is referring to the group he was in prior to the study in the Fall of 1992. The "David" he mentions is not the ENNL student in the third case study, but another student with the same name.)

MD. OK. So you felt better. So it depends on what group you're with and what the group does, as far as working together, on how you will feel?

Chandra: Yeah.

MD: $\quad$ So if you're with a group that does not work together as well can

Chandra: Yeah. you not feel as good about yourself? 
My final question in the interview dealt with the increased participation in the whole class discussions. I had observed an increase in the level of participation of all threc ENNL students during the sex education unit when I was handing out tickets for oral participation. The increase in whole class discussions had taken me by surprise. I had expected less participation or no change in the level of participation since we were dealing with the subject of sex education. I wanted to know the reason for the increase so I asked each of the students about this trend as their final interview question. When I asked Chandra why he volunteered so often during the family life unit, he replied, "Because I learned and the tickets were counting on my grade."

\section{Summary of Chandra's second group experience.}

Chandra was an active member of the $\mathrm{CL}$ group in this placement. He was more involved in helping the team or his partner complete the task or assignment. His group members engaged in conversations with him more often, even addressing questions to him. He was heard laughing, joking and arguing. He indicated on both surveys and in his interview that he felt better about himself and his work in this group. He said that in this group he talked to everybody and shared answers. He also participated more extensively than before in whole class activities.

\section{Comparison of Chandra's Two Group Placements.}

Chandra had a different experience in his second, self-chosen, group placement. In the sccond group, he was an active member. In the first group, his contributions were not welcomed. The first group excluded Chandra both physically and verbally. When he attempted to engage the group in conversation, his group would only respond briefly, if at all. Both the tapes and my observations revealed that this was not the case in the second group. Here he participated in conversations and the activities. He was asked questions by team members about himself and about science concepts. In this second group he patiently 
helped Ned, a special education student. In the first group, Chandra did not enjoy the same status as in his second group.

It is not surprising that Chandra's self-esteem was affected by his group placement. While a member of the first CL team, his self-esteem was lower than it was while he was a member of the second CL team. He placed more value on his work and role in helping the group in the second placement. The interviews indicated that he perceived a difference in the two placements. He said he felt the best group placement was the second one because "everyone got to do the work and no one was left out."

The group placement, and Chandra's status within that group, emerge as important factors in how he felt about himself and his work.

\section{Second Case Study: Minh \\ Background}

Minh is a twelve year-old girl in the sixth grade. She was born in Vietnam and arrived in the United States in January, 1991. At the start of this study she had been in the U.S. for two years. Her primary language is Vietnamesc. She was born the middle child between two brothers. She lives with both parents. She is small for her age. She attended school for four years in Vietnam and spoke no English upon her arrival here. She can often be found hanging around the school campus long after the other students have gone home to help out one of several teachers. Here in the U.S., her favorite school subjects are spelling and drawing because she feels she is good at them. Her least favorite subject is social studies because of tests she cannot read or understand. She says she likes working in groups. When I asked who she would choose for teammates if allowed to form her own cooperative learning group, she listed two girls. Both were "A" students in science. She explained that these students would 1) be nice to her, 2) help her when she needed it, and 3) let her talk. 
First Group Placement: Findings From Audio Tapes, Field Notes, and Video Tapes.

Minh's first group placement consisted of herself, another girl and two boys. During the research, one of the two boys moved, so there were only three group members for the second half of this group placement. In this first placement, Minh was an active, participating member of her CL team. I observed her on many occasions lcaning forward along with other group members. This group often worked in close proximity to one another. They shared their work during labs. I saw Minh assembling the circuits with her other group members. When I would ask the group if everyone was playing a role in performing the lab, they would answer, "Yes," and could then go on to explain what each individual was doing. Minh's role would usually involve manipulation of the lab materials, a very' appropriate role due to her limited writing skills. For example, during the circuit lab, she was one of the circuit builders. She helped with the attachment of the wires. In another lab, she was the materials getter. This person would get and return all lab materials necessary for the experiment.

Minh's role within the CL group was not limited to physical proximity and manipulation of materials as she also contributed to the group effort verbally. She of ten questioned the group and offered suggestions through questions. Of her 31 recorded utterances in this group, 10, almost one-third, were questions (see Table 5). 
Table 5

Types of Uttcrances: Minh's First Group Placement

\begin{tabular}{|c|c|c|}
\hline Type of Utterance & \# of Utterances & \% of total \\
\hline Questions & 10 & $32 \%$ \\
\hline Answers & 8 & $26 \%$ \\
\hline Statements & 13 & $42 \%$ \\
\hline Totals & 31 & $100 \%$ \\
\hline
\end{tabular}

In this first example, the group was doing an insulator/conductor lab. They had brought items from home to test and are attempting to decide what to test first:

Rachel: We don't know what were going to test.

Minh: Wires?

Rachel: $\quad$ You put paper clip, wire. Paper clip, metal.

Edward: Everyone put it.

Minh: $\quad$ Paper clip, metal.

Other times, Minh would inquire about how to say things:

Minh: How you say [inaudible]?

Rachcl: We're not suppose to put anything [inaudible].

Minh: I want to.

Minh's group usually responded to her questions, especially the other female member, Rachel.

Minh not only asked questions; she answered them as well. Of the 31 recorded utterances, 8 (or 26\%) of them were responses to questions (sce Table 5). Four of these were responses to questions I asked as the teacher, while the other four were responses to group questions. Her answers reflected that she had some understanding of the science concepts being taught. In this group, $19 \%$ of her utterances reflected concept understanding (see Table 6). 
Table 6

Class of Uttcrances: Minh's First Group Placement

\begin{tabular}{lcc}
\hline \multicolumn{1}{c}{ Class of Utterances } & \# of Utterances & $\%$ of total \\
\hline $\begin{array}{l}\text { 1. Activity Related } \\
\text { 2. Reflecting Conceptual } \\
\text { Understanding }\end{array}$ & 17 & $55 \%$ \\
3. Unrelated to Activity & 6 & $19 \%$ \\
4. Insufficient to Code & 6 & $19 \%$ \\
$r$ Totals & 2 & $7 \%$ \\
\hline
\end{tabular}

On one occasion, this understanding was heard while the group was completing a study guide for an upcoming quiz.

Rachel: $\quad$ OK, number onc.

Minh: Ability to work. (This is the correct answer to question number

Rachel: Yeah, ability to do work.

Later, during that same assignment:

Rachel: The seven types of energy

Edward: Heat, sound.

Minh: Heat

Rachel: $\quad$ Heat, sound... mechanical

Minh: Heat, sound...musical...mechanical, light.

Rachel: $\quad$ Magnetic.

Minh: $\quad$ Electricity.

Rachel: $\quad$ Light, electric, and chemical. Energy can be transformed from one type to another by, by what? How can it change?

This group waited for members that needed additional time to complete responses.

They also checked to make sure all the members were ready to go on.

Rachel: Does everyone have it?

Minh: No.

Rachel repeated the answer for Minh.

It is important to note here that the person that responded most often to Minh was

Rachel. Rachel was patient with Minh, and she set the tone for the group. Rachel was the 
group leader and all members would look to her with questions and would follow her directions without complaint. Group leader was not an assigned role. I made this determination from my observations and listening to the audio tapes. Rachel was not a pushy leader, nor did she save all the best jobs for herself. It was obvious as I observed this group, that all members respected Rachel.

Other group members did not always respond to Minh. For example, during that class period where the CL groups were given the opportunity to work on a study guide to help prepare for an upcoming test, Rachel noticed that Joey had not been completing all the answers the group had discussed on the study guide.

Rachel: $\quad$ You don't even have them all, Joey.

Joey: I know. I got 1,2,3,4, chemical right there.

Minh: I done with this. Define energy. Ability to do work. Number two. Cite two forms. Potenial (attempting to say "potential") and kinetic.

Joey did not pay attention to Minh's attempts to help. Instead, he discussed what was missing from this sheet with Rachel. During this time, Minh continued to read the questions they had completed as a group along with their answers. Although Joey did not respond to Minh's answers, neither did he tell her to, "Shut up," something I had observed him commonly do in other groups where he had been a member.

Another indication that Minh considered herself a full member of this group was the fact that she appointed herself to the role of group noisc monitor. Minh revealed later, in her interviews with me, that one of the ways she would judge whether she was in a good group placement was by how the group members responded to her in this role (this will be covered further in the discussion of her interview). Minh would verbally call for quict when the group or an individual group member (most of ten Joey) got loud. She could be heard on the audio tapes saying "Shhh" or "Quiet" on more than one occasion. The group would sometimes respond by lowering the noise level and other times the group would not respond. 
Minh did not of ten volunteer to answer questions in the whole class setting while she was a member of this group. There were times, though, when she would have to respond or forfeit the opportunity to carn points for her team. One of these occasions occurred during her first group placement. We were playing a review game for bonus points. Review games were normally played prior to an upcoming test or quiz. The purpose of these games was threefold: to review the test material in a fun manner, to convince some of my students they needed to study this material before the test, and to give the team the opportunity to earn additional bonus points. Bonus points were given to teams for a variety of reasons-all group members turning in their homework, being one of the first teams quiet when I asked for it, or working well in their cooperative team. Before we switched teams we would total up the points each team had earned. The top two teams received prizes. All team members had to participate during bonus point games. Bonus points were highly valued by class members as evidenced by the fact that many of them would stay after class to determine which team currently had the most bonus points.

On this particular occasion, I had given all team members a number. I would first select a "rcady" group, one that was quiet and focused so they could hear the question. Then, I would call out a number. The team member with that number would answer the question. During the game, Minh's number came up.

MD: Minh, give me one, or more than one reason [we know a chemical reaction occurred].

Rachel: $\quad$ (quietly) Number six.

MD: (speaking to the whole class) Listen carefully because if she doesn't get them all I'm throwing it back out.

Edward: (quietly) Number six.

Minh: $\quad$ (reading a response from her study guide) Ah...so...ah we can learn how plants make their own ...

MD: $\quad$ No. No. Go up! Do the next one. Number five.

Minh: Number five?

Edward: $\quad$ Oh, it was number five?

Minh: (with more confidence) Oh, the chemical reacted because the bag get hot. 
MD: $\quad$ OK, number onc, the bag got hot. Heat is given off. That's one reason we know a chemical reaction occurred. Did you writc that down?

The next two answers were supplied to Minh quictly by her team members. They gave the answer to her while I was addressing the large group. ${ }^{2}$ Minh was able to give two additional reasons. Her team received a total of three bonus points for her answer. They were very pleased and so was Minh. If Minh was not "required" to participate in the whole class discussion, she sat quietly.

\section{Findings From Attitudinal Surveys and Interviews.}

In Minh's first two surveys, following a cooperative group circuit lab and the group book and given while she was with this group, Minh rated her work as "high" and "important." Minh indicated she enjoyed both activities very much and liked school more after participating in them. Her surveys said she felt some pressure during the cooperative group lab and a lot of pressure during the book making. In both cases, she indicated she felt better about herself after doing the activities.

In her interview, Minh asked for a clarification of the word "rate." I explained what the word "rate" meant in terms of this statement. I explained further that she had rated her work as really good. Before I could complete the entire example, Minh jumped in with:

Minh: $\quad$ Because that day when I just come here and that day I didn't know anything and I didn't to do and now I come here and that I thought that day I know better than the first day I come here.

I asked Minh why she indicated on her surveys that she felt better about herself after these activities. Minh gave this question considerable thought before responding.

Minh: Because ...ah.. the group was working together like ah... when after you changed the groups into each table like ah...that group was better than the first group you chose for me. (Minh is referring to the first group in the study. She had been in another group prior to the beginning of the study.)

\footnotetext{
I am aware that group members support a team member in this way and unless I have specifically advised that answers may not be discussed during the game I allow these conversations.
} 
Me: $\quad$ So it does make a difference what group you sit with?

Minh: Humhuh.

The day of the interview, I had the students form the groups that comprised the second group placement. I asked Minh how she felt about her new group. She expressed concern about one of the male members of her group, David, saying that he would not listen to her when she asked for quiet. This "David" is not the same student that is the subject of the third case study. This David is extremely talkative and loves getting my attention. He often will not be quiet even after I have asked him. As previously discussed, Minh felt that one of her roles in a CL group is to maintain a reasonable noise level and help keep the group on task. In this first interview, she was indicating that she had some trepidation about how well her new group would work together because this one individual talked a lot, even when she asked for quiet.

I asked Minh why she enjoyed the circuit lab and the book making so much. She expressed being part of what was happening with the group was important to her. She explained that she helped with the writing and the drawing of the book. Her ideas were included. This led me to ask:

MD: Is it important to be involved in the group?

Minh: $\quad$ Yeah.

MD: $\quad$ Why is it important to be involved in the group?

Minh: $\quad$ (after a long pause and reassurance from me that she was "doing fine") Because...um...if the the...I only work by myself I can't do it. But, with them I could do it.

Me: $\quad$ OK. You can do it better with them. Why don't you think you can do it by yourself?

Minh: Because...um... Because I didn't...somewhere I didn't know what it mean but I don't know what it write them all. So, they can write.

MD: $\quad$ OK. So sometimes language makes it harder for you to do the work.

Minh: Umhuh.

MD: Does language make it harder to work in the group? Sometimes

Minh: Yeah. 
I asked her what she does when her group doesn't understand her. She said without hesitation:

Minh: $\quad$ You say. "Huh?!"

$\mathrm{MD}$ : $\quad \mathrm{OK}$, and what happens then?

Minh: I just forget about it.

I asked Minh whether she thought learning was better for her with a group or without a group. She responded that it was better in a group. I followed up this question with another question asking why she felt her learning was better with a group.

Minh: $\quad$ Because they help me a lot. They help me ..uh.. the word I don't know.

MD: Do they help any other way?

Minh: Like they show me... like the work I don't know: Then, they help me.

\section{Summary of Minh's First Group Experience.}

Minh was involved and active in the activities with this group. She could be seen bent over a task along with her teammates. Her communication included questions to which her teammates usually responded, especially Rachel. She also attempted to help team members with answers when she had them. Her communication did reflect that she had some grasp of the concepts being taught. Minh would "police" the noise level of her group, reminding members to quiet down when they became too loud or were off task. She indicated that language sometimes made it difficult to communicate with her group members but she did not worry about it. Her surveys and interviews indicated that with this group her selfestecm was high and she felt her work was important and contributed to the group.

Minh's Second Group Placement: Findings From Audio Tapes, Field Notes, and Video Tapes.

The second group placement for the students was the one in which I let them select their own group members, based on the criteria I gave them. It is important to note that on this day, Minh was late arriving at class. She had been helping another teacher and by the 
time she arrived, many of the groups were already partially formed. Minh found a girl, Vicki, that she wanted to work with, and together the two girls joined a pair of boys. I am not certain that Vicki would have been Minh's first choice to work with if she had arrived on time. I am almost certain, however, that she would not have selected the two boys as team members.

Minh and one of the boy members, David, did not seem to get along well. This was the student that she had expressed concern about in her first interview. Short conversations also indicated that these two were somewhat antagonistic towards each other.

David: We're done. [Pause] Minh, be quiet.

Minh: You be quiet. I don't want to be quiet. David, I'm not talking, you are.

Another time, David spoke directly to the tape player that was recording that day's group conversations. David seemed very interested in this tape recorder. When he spoke to or touched the recorder, Minh would become very annoyed.

David: $\quad$ Hi, Mrs. Dimas.

Minh: (emphatically) Stop it, David.

And on another occasion,

Vicki: $\quad$ (to David) Stop messin' with it.

Minh: (upset) David, David, get her pencil. It, David. David, you tried to turn it off.

As in her first group, Minh assumed a role of noise monitor. She could be heard saying "Shhh" and "Quiet" on the tapes. These comments were most often dirccted at David.

Minh's conversations with the cntire team werc less in this group than with her first team. She did, however, have long conversations with her partner, Vicki, during the pair activities. Vicki was a special education student. In these conversations with Vicki, Minh answered questions and often took the lead (sce Table 7). These conversations were about 
Table 7

Types of Utterances: Minh's Second Group Placement

\begin{tabular}{|c|c|c|}
\hline Type of Utterance & \# of Utterances & $\%$ of total \\
\hline Questions & 13 & $21 \%$ \\
\hline Answers & 12 & $19 \%$ \\
\hline Statements & 37 & $60 \%$ \\
\hline Totals & 62 & $100 \%$ \\
\hline
\end{tabular}

the science activity and often showed that Minh had an understanding of the science concepts being taught. Of the 62 recorded utterances in this group, 39 utterances (or 63\%), related to the activity being performed and 14 utterances (or 23\%), reflected understanding of scientific concepts (sec Table 8). Threc examples of conversations relating to the science

Table 8

Class of Utterances: Minh's Second Group Placement

\begin{tabular}{lcc}
\hline \multicolumn{1}{c}{ Class of Utterances } & \# of Utterances & $\%$ of total \\
\hline $\begin{array}{l}\text { 1. Activity Related } \\
\text { 2. Reflecting Conceptual } \\
\text { Understanding }\end{array}$ & 39 & $63 \%$ \\
3. Unrelated to Activity & 14 & $23 \%$ \\
4. Insufficient to Code & 5 & $8 \%$ \\
$\quad$ Totals & 4 & $6 \%$ \\
\hline
\end{tabular}

activity and reflecting concept understanding follow.

In this first conversation, the girls are participating in a genetics lab on dominant and recessive traits. They were determining whether traits evidenced in their own bodies werc caused by dominant or recessive genes.

Vicki: $\quad$ Did my tongue fold?

Minh: $\quad$ Yeah. No. You have to do it. You can't touch anything. 
During a partner quiz. on genetics:

Minh: $\quad$ Our monster has a dominant...

Vicki: $\quad$ A dominant body.

Minh: No, a dominant red pair.

Vicki: (writing) A...dominant...

Minh: $\quad$ Red pair.

Vicki: A...dominant...red...pair... of genes.

Later in this lab:

Vicki: $\quad$ Z, what was Z?

Minh: $\quad Z$ was a...tail.

Vicki and

Minh:

Minh:

Vicki:

Minh:

Vicki:

Minh:

Vicki:

Minh:

Vicki:

David:

(together) Our monster has

has a ... de not

Demonate

No, demonante. No, deminan...

David, what is this word?

(David does not respond)

Dominant.

Wait, dominant?

Yes, it's dominant.

On more than one occasion, Minh read the directions for the activity or quiz for the partners. It was interesting to note that she would get almost "bossy" with Vicki. During the same baby monster quiz, Minh indicated she would do the drawing:

Minh (reading directions for the quiz) OK, now your monster. Include all the traits and write about her.

Vicki: $\quad$ OK, ready.

Minh: $\quad$ Let me draw it.

Vicki: $\quad$ OK, here. You use the [inaudible] pencil. It's better. I get to color it.

Minh: $\quad$ OK, but I get to tell you. I'll tell you.

Vicki: Draw it big.

Minh: Draw what?

Vicki: $\quad$ The monster.

Minh: I don't know how to draw a monster. Two eyes?

Vicki: Two eyes.

Upon occasion, as in the above conversation, Minh did ask questions. Of her 62 recorded utterances, 13 were questions. In other words, $21 \%$ of her recorded utterances were questions (see Table 7). In this group, these questions seemed to be addressed only to 
Vicki or the teacher. She did not ask either boy a question in any of the taped conversations.

Here is an example where Minh is asking Vicki for the meaning of a word. This example is again during the genetics quiz.

Vicki: It has claws

Minh: What is claws?

Vicki: $\quad$ Like long...

Minh: [inaudible] Oh, I know is claws.

An example of a question she asked me occurred when she and Vicki were working as a pair on a particularly difficult worksheet. Minh got my attention and then said:

Minh: We don't know what number three is [inaudible]

MD: Hum?

Minh: We don't know what rectum means.

MD: $\quad$ OK, skip it and do the ones you do know first. Then go back to the ones you don't know.

Minh: I, we don't even know nothing on this.

MD: You don't know what sperm is? You don't know what puberty is?

Minh: No.

As noted before, Minh did a lot of talking with her partner during partner activities and not as much with the entire group. Near the end of the unit her regular partner was absent for several days. Minh's involvement in this group had been almost exclusively with Vicki. With Vicki absent, the number of Minh's utterances decreased. During this time I did observe her occasionally conversing with the two boys in her group. She also made comments directed at no one in particular.

Minh: Dang! Look at the rubber band. It broke. Great, whatever.

During one of the days her partner was absent, I assigned a girl from another group to work with Minh. Edith did not have a partner for this activity. I did not record this day on audio tape, but did have it on video. The two boys did work together but Minh did not bring herself into physical proximity with her partner like she had done with Vicki or within her first group. The distance between them was so great that I actually had Minh 
move her chair closer to her new partner. There was not a lot of conversation between the two partners as they worked on their task and sometimes Minh would talk to the boys instead of her partner. It is interesting to note that Minh secmed more comfortable with the boys that she previously had not gotten along with in her group rather than this new female partner. I am not aware of any reason that Minh would have been uncomfortable with Edith.

Minh participated more on the whole group level during the period that tickets were being passed out. It did not happen the first few days, but by the start of the second week her hand was frequently up and she answered most questions correctly when called upon.

\section{Findings From Attitudinal Surveys and Interviews.}

The surveys taken while with this group showed a difference in most areas. Minh no - longer rated her work as "high." In both surveys, it was now rated "medium." She indicated the importance of her contribution as "somewhat important" in both cases. These surveys were given after an activity where the group worked together for a short time followed by a longer period of whole class discussion of the work done and after a pairs activity. It is very important to note that Minh's regular partner was absent the day the pairs survey' was given. There was no opportunity to give Minh another survey after working with Vicki, as Vicki's absences continued until the end of the school year.

After the activity with large group time, she said she felt about the same about herself. After the partner activity without her regular partner, she indicated she felt worse about herself. Her enjoyment of the activity was "OK" for large group and very much for the partner activity. Her open-ended responses were "a little bit good" and "OK." She felt she expericnced some pressure in both activities. 
In her linal interview, Minh spoke highly of her partner experience with Vicki. She said her favorite type of activity and the one she communicated the most in was the pairs. I asked her why.

Minh: Because if groups, if you're working with groups then... um...um... you didn't get your chance to talk to them. To do work. When you work in pairs you can talk to [inaudible].

MD: $\quad$ So you're saying when you worked in pairs you got your chance to talk

Minh: $\quad$ (interrupting) Umhuh. Yeah and do and do some activity a lot of the time.

Minh indicated she learned the most in the large group time when I was teaching. I asked about my observation of her volunteering much more often in the large group setting once I started handing out tickets. I asked her why her hand went up so much.

Minh: $\quad$ Bccause, um...I know a lot...um... a lot of things about that.

MD: $\quad$ OK, so you knew a lot about this

Minh: (interrupting) You taught me

MD: $\quad$ OK, so because of the way I was teaching it, you felt you knew

Minh: the answers Yeah, yeah.

MD: $\quad$ and then you could raise your

Minh: $\quad$ Yeah

MD: Did getting a ticket have anything to do with why you raised your hand?

Minh: Um, it makes your grade go, go up.

MD: $\quad$ OK, so when you got a ticket you saw your grade go up?

Minh: $\quad$ Uh huh

MD: $\quad$ And you wanted your grade to go up?

Minh: Uh huh.

In the interview, Minh indicated that she felt no difference about herself after a $\mathrm{CL}$ activity. This response did not correspond with either her survey responses or her observed and recorded behavior. I could not get anything further from her on this topic, even after restating the question. It is interesting that she did not seem conscious of an effect on her self-esteem from the CL group placement although her surveys and group behavior indicated that a relationship did, indeed, exist. 
When I asked her about her favorite group she said she could not remember who had been in past groups. I approached this question again by giving her some of the names of persons in her past group. It did not seem to jog her memory and she indicated that she did not remember.

\section{Summary of Minh's second group experience.}

Minh had long conversations reflecting science concepts during activities when she was with her regular partner, Vicki. She did not seem to care for one of the group's male members and seems mainly to address remarks asking for quiet or to stop doing certain things at him. She did not talk of ten to the boy members of this group. While working with the whole team and her temporary partner she did not show the same physical (body) language of bending into the group or activity that she had shown with her first group. Her surveys indicated that while with this group she did not rate her work as high or as important as with the first group. She also indicated that after activities she felt the same or worse. In her interview she said she enjoyed and communicated more in a partner setting but learned more in the whole group setting. The interview process was a bit more difficult with Minh. She did not provide the details I had hoped for and she seemed to have difficulty answering some of the questions. She had indicated to me in the first interview that sometimes the learning of English interfered with her understanding. This may have been the problem in this interview.

\section{Comparison of Minh's Two Group Placements.}

In Minh's first group placement she was an active, involved member-in-full of the group. She asked and answered questions. Her group, under the leadership of Rachel, responded to her. The second group experience was not as positive as the first. Her choices for team members were limited by the fact that she arrived after the activity to choose members was already underway. She enjoyed the partner activities with her regular partner, 
Vicki. Here, she was the leader and could be seen and heard helping Vicki, a special cducation student. She did not enjoy full member status within the total CL group in the second placement. Minh and David did not get along well. She did not rate her work as high or as important as she had in her first group placement. She also indicated that she felt "the same" or "worse" about herself after the activities. The group placement, and Minh's status within the group, emerge as important factors in how she felt about herself and her work.

\section{Third Case Study: David}

\section{Background}

David is a fourteen year-old boy and is also in the sixth grade. He was born in the Philippines. He arrived in the United States in October, 1991. His primary language is Itocano. He is the youngest of five children. David lives with his mother and his four brothers and sisters. He did not mention his father at all. He attended school in the Philippines. His fifth grade teacher indicated that his attendance had been sporadic. He lived a portion of his life in the Philippines on the streets. He was initially classified as nonEnglish speaking upon his enrollment in elementary school. He has since been reclassified as LEP. There is concern about David's progress in school. He has been placed in a special cducation program for math and language arts.

David seemed to have a more difficult time adjusting to school here in the U.S. than either Minh or Chandra. During his first year in the U.S., he would run away from school, hide behind buildings, of ten cry, and frequently swear in English. David had been left in the care of an older brother for several years while still in the Philippines (ages two through nine). During this period, his mother came here to work. During the study year, David no longer left the room when things weren't going too well, or cried at school. The swearing had also decreased. He is very sensitive about the fact that he is older than the other sixth 
graders and will lic about his age. In my initial intervicw he lied about the year he was born so he would seem to be the same age as the other sixth graders. David seemed concerned with receiving my approval and it appears this desire may have influenced his responses to some of my questions during the interviews. Here in the U.S., his favorite school subject is science. He says he loves to mix chemicals. His least favorite subject is math. He said it is hard to do it in his head. When I asked him if he liked to work in groups, he said sometimes, if the group was helping each other and not just talking and playing around. When asked to choose his ideal cooperative learning group, he chose one boy and two girls. When I asked him to explain his choice he said that they would not be talking and that the boy member would help him.

\section{First Group Placement: Findings From Audio Tapes, Field Notes, and}

\section{Video Tapes.}

David's first group was made up of three girls, two boys, and himself. One of the boys was absent more often than he was present. David did not often show physical signs of involvement in the task while in this group. He sat at the end of the table nearest the door. I never observed him bend into the group or lessen the distance between himself and other team members or between himself and the task. David and the girls in his group had difficulty cooperating. In fact, at times they seemed antagonistic The girls in the group would "tattle" to me about what David was or was not doing. During one cooperative group lab, I indicated that each team member must complete their predictions on their individual lab sheets before the team could pick up the lab equipment. David was trying to complete the lab sheet on his own without help from his group. With his limited writing abilities in English, David was proceeding very slowly.

Edith: He's trying to get us in trouble.

Mary: I know that's all he's doing.

Edith: Come on start writing. I want to get done today.

Mary: Hey, David....I'm going to get Mrs. Dimas. 
MD: $\quad$ OK, let's get our stuff written down here.

Edith: Everyone's done except him.

MD: Well, can we maybe help instead of being accusatory. Does it help any to finish carlier if you're accusing him? We've got to remember here that David has a slight disadvantage when it comes to writing English and instead of yelling at him maybe we could help him and move a lot faster.

Jimmy: They're yelling at him. I wasn't saying anything.

This was not the only taped example of the girls indicating that they would tattle on David.

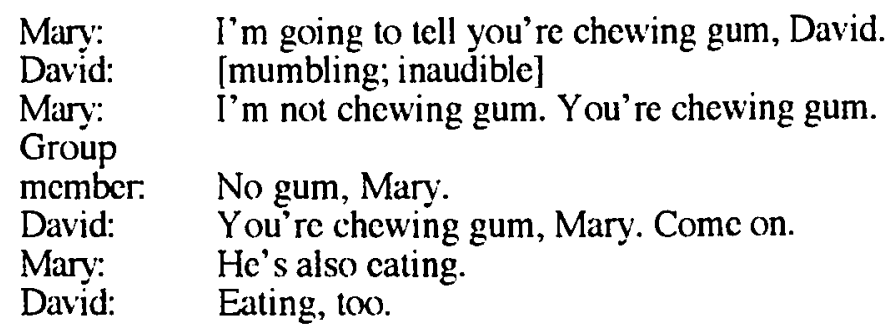

In the above conversation, Mary and David argued with each other. The audio-tape conversations revealed that, of the girls, Mary seemed to go out of her way to get David in trouble. At one point Mary was heard saying, "I hate this table. [pause] We're always last becausc of him." Mary is referring to David.

The group made little or no accommodation to include David in the group. They made little effort to involve him in an activity unless specifically requested or instructed to by me. When I made it clear that everyone in the team most be involved, David would be assigned a task that he did not want or was beyond his understanding or abilities. For example, during planning for the group book, David was identified by the group as a good artist. Instcad of assigning or offering him some of the drawing in the task, they assigned him a task which involved no drawing and which was, frankly, beyond his English abilitics.

Edith: Who can draw good? Mary and David. I can do number OK, three will be Mary. (Edith is using the assignment and grading criteria sheet I had just passed out to assign parts of the task. This was not the intended purpose of the handout.) Mary you're doing the cover.

David: I'm doing number two.

Edith: $\quad$ No, I'm doing number two.

Mary: I want to do the cover.

David: I want to do number two. Come on. Who's doing number five? 
Edith: You.

David: $\quad$ NO.

Edith: What do you do on number five?

David: I'm number two. I want to do number two.

The argument with Edith continucs until I arrive at the table to collect the homework assignment. After my departure, David asks to see the story for the book. The whole group was supposed to be composing the story but in this group only Christy was doing the writing. She told him he couldn't see it. He then asks for paper.

David: $\quad$ Give me paper.

Mary: Why, you' re not doing anything?

David: What?

Mary: What are you going to do then?

Edith: You're doing number five.

Jimmy: He's doing scientific knowledge?

It is important to note that some of David's drawings were included in the finished book. I am not certain about how this came to pass. This was a multiple-day activity. As there was a substitute teacher for the final two days of the activity, I did not have any taped conversations or observations for those two days.

As these conversations illustrate, much of David's communication in this group takes place during an argument or a confrontation. He rarely asks questions of other group members. Of the 38 recorded utterances in the first group placement, only 7 (or 18\%) were questions (see Table 9). Three of these questions were directed to me. Another 28

Table 9 Types of Utterances: David's First Group Placement

\begin{tabular}{|c|c|c|}
\hline Type of Utterance & \# of Utterances & $\%$ of total \\
\hline Questions & 7 & $18 \%$ \\
\hline Answers & 3 & $8 \%$ \\
\hline Statements & 28 & $74 \%$ \\
\hline Totals & 38 & $100 \%$ \\
\hline
\end{tabular}


utterances (Or 74\%) were classified as statements (sec Table 9), 19 of which occurred during an argument or confrontation. David's utterances were usually short, and only $8 \%$ of his recorded communication with the group reflected understanding of science concepts (see Table 10). There was an occasion on one tape where David did attempt to help his

Table 10

Class of Utterances: David's First Group Placement

\begin{tabular}{lcc}
\hline \multicolumn{1}{c}{ Class of Utterances } & \# of Utterances & \% of total \\
\hline $\begin{array}{l}\text { 1. Activity Related } \\
\text { 2. Rellecing Conceptual }\end{array}$ & 33 & $87 \%$ \\
$\quad$ Understanding & 3 & $8 \%$ \\
3. Unrelated to Activity & 1 & $2.5 \%$ \\
4. Insufficient to Code & 1 & $2.5 \%$ \\
$\quad$ Totals & 38 & $100 \%$ \\
\hline
\end{tabular}

group. At one point, they were discussing the still incomplete story Christy had been writing. They were trying to come up with an appropriate drink for their characters who were dining in a French cafe.

Jimmy: $\quad$ A cup of Kool-aid?

Christy: A cup of soda?

Mary: What do they drink in France?

David: Jimmy...Jimmy...Herc. Done....Jimmy

Christy: How do you spell cappichino?

David: $\quad$ You have to an h. Chino. Put an h.

Aide: (bringing a dictionary with her to the group) Seems like there

David: $\quad$ Ohould be two p's. You said cap-...cap-pichino.

Aide: I don't know, that doesn't look right yet.

David: $\quad$ Yes, yes it does. Cap...cappichino.

Edith: $\quad$ OK. I'm done with the title page. Let's put it all in order.

David: That's right, double $\mathrm{p}$. It say cappichino.

David did not volunteer to answer my questions during whole class lessons or discussions. He did respond when I called on him. I was calling on students to check for understanding: 
MD:
Wavid? (The other David in the class responds.) The other onc.
What's going to happen when a negative charge and a positive
charge come together? When two oppositc charges come
logether, what's going to happen, David?
David: Atract.
MD:

Findings From Attitudinal Surveys and Interviews.

David's interview revealed that, even though I had been over the attitudinal survey forms more than once, he still had some difficulty with some of the language on it. Expressing himself in the interview was a little more difficult for David than for Minh or Chandra. David also seemed to be searching for the "right" answer, perhaps the one he thought I wanted to hear. He was embarrassed if he caught himself in a mistake and would try and cover it up. For example, on one survey he wrote in the open-ended response that after today's activity I felt..."happy because I cleaned my house and did my homework." When it came time to discuss this response in the interview, I asked him why he put this and he responded that he had meant to put circuit lab. Even when I explained that this was his survey and this was a "correct" answer if that is how he felt at the time, he still insisted that he had meant to put he felt good after the circuit lab. Nothing on the survey or during the interview indicated that he felt good during the circuit lab. Still I do believe the surveys and the interview gave me some valuable information.

David indicated during the interview that he did not understand the word "rate." The rating answers on the first two surveys may, therefore, be invalid because of this. We did have an interesting conversation about his work, however. I told him that he had rated his work as "high" on the survey. He did have a reason for this.

David: $\quad$ Because I was going to do circuit and they didn't let me.

MD: $\quad$ Oh, you wanted to do the circuits. They didn't want you to do the

David: Yes.

MD: $\quad$ And did you try to do the circuits? Did you do any part?

David: $\quad$ [inaudible] because the group didn't want me to.

MD: Why didn't the group want you to? 
David: I don't know.

MD: $\quad$ Does that upsel you when the group doesn't want you to?

David: I don't like that.

David explained he rated his work on the book as "medium" because he worked in the middle. David had skipped question number seven on both surveys, the question that asked him to rate the importance level of his work in helping the group solve the problem. Next, I asked him about his enjoyment level regarding the two activities. He had indicated on his surveys that he enjoyed the book very much and the circuit lab was $O K$.

MD: Did you enjoy the activities? You said the circuits was okay. Why

David: $\quad$ did you say it was okay?

MD: $\quad$ Say again. [Pause] You didn't say you enjoyed it very much, you didn't say you enjoyed it not at all. You said that it was okay. "I

enjoyed it okay." Why did you say okay?

David: I enjoyed it not very much.

MD: $\quad$ Not very much, but you sorta liked it.

David: $\quad$ Yes

MD: $\quad$ Would you have liked it more do you think if your group had let you do part of the building of the circuits?

David: $\quad$ Yeah.

MD: Do you think your answers might have been then that you

David: $\quad$ Very much.

David indicated he liked the book activity very much because, "Cuz, they were working and I worked too. We wcre working together."

David indicated he liked school more after the book activity. David also indicated that while he felt the same about himself after the circuit lab, he felt better about himself after the book activity. I asked him why he felt the same about himself after the circuit lab and better after the book.

David: Because when I was working on the circuits...umum...I was the same.

MD: $\quad$ Same. You didn't feel better and you didn't feel worse either?

David: Yes.

MD: Here on the book though, you said "I felt better about myself." Why did you feel better after doing the book.

David: I draw the book. I draw Edgar.

MD: $\quad$ You drew Edgar in the books. 
David: $\quad$ Yes.

MD: $\quad$ And that makes you fecl good?

David: $\quad$ And I color.

MD: $\quad$ And you colored it. And does it make you feel good when you do something with the group?

David: I'm happy when I do something with the group.

David's open-ended response on the survey confirmed what he was saying in the interview. "After today's activity I felt..." "I felt like good because I helped."

When I asked him whether not knowing English really well could be a problem, he nodded and said, "About spelling." I asked if talking with the people in your group was a problem and he said, "It not problem."

\section{Summary of David's First Group Experience.}

David did not often have the opportunity to get very involved in the activities with this group. His communication was usually part of an argument with another group member. He did not volunteer to participate in the whole class setting. His communication did not often reflect understanding of science concepts being taught. His surveys and interview indicated his self-esteem was not adversely affected by working in this CL group even though he was often not included and did not enjoy full-member status in the group. The girls in this group, especially Mary, seemed to dislike having David as a member of the group. David indicated a positive effect on his self-esteem, on his surveys and in his interview, after the book making activity. During this activity, he participated and his work was included in the final group product. He was very proud of this fact. David also had some difficulty with one or more of the phrases on the survey.

\section{David's Second Group Placement: Findings From Audio Tapes, Field}

\section{Notes, and Video Tapes.}

David's second group experience took place in a group of four consisting of two girls, one boy, and himself. This is the group placement that David selected for himself. In this 
group, David's communication was different. First, it did not normally occur as part of an argument. There was only one cxample of an argument in the taped conversations. This occurred during a period when students were working on sex education worksheets as partners or in $\mathrm{CL}$ groups. Talking to each other about the material was acceptable This “argument" was on a non-class related discussion that David started with his group.

David: Edward, whose that guy again, the king?

Edward: Yeah?

David: $\quad$ That one on the TV., the one on the TV., TV.. His last name is King?

Edward: Rodney King?

David: $\quad$ Yeah. He got fifty thousand, fifty million.

Shirley: Dollars?

David: Yeah.

Shirley: Shut up!

David: He did.

Shirley: Fifty Million?

David: Yup.

Shirley: $\quad$ Edward, how much did Rodney King get?

David: Fifty, fifty.

Shirley: He did not get fifty million.

David: He did.

Shirley: $\quad$ No, he didn't.

David: He did.

Linda: Fifteen

Shirley: Five-zero?

Linda: $\quad$ Fifteen. He got fifteen.

David: It's fifty million.

Linda: $\quad$ Fifteen.

David: Ohhhh... And the camera man.

Linda: What cameraman?

David had other conversations in this group that had nothing to do with the science activity in which he was supposed to be engaging. Twenty-seven percent of the utterances in this group were not related to science or the current activity, compared to $2.5 \%$ in his first group (sec Tables 10 and 11). Most of these conversations took place with the other male group member, Edward. David seemed to have found a friend in Edward. They talked about personal things. Edward showed David an advertisement Linda had brought in for 
Table 11

Class of Utterances: David's Second Group Placement

\begin{tabular}{lcc}
\hline \multicolumn{1}{c}{ Class of Utterances } & \# of Uterances & $\%$ of total \\
\hline $\begin{array}{l}\text { 1. Activity Related } \\
\text { 2. Reflecting Conceptual }\end{array}$ & 42 & $56 \%$ \\
$\quad$ Understanding & 10 & $13 \%$ \\
3. Unrelated to Activity & 20 & $27 \%$ \\
4. Insufficient to Code & 3 & $4 \%$ \\
$\quad$ Totals & 62 & $100 \%$ \\
\hline
\end{tabular}

the advertising with sex appeal and without sex appeal assignment. Students were required to find one advertisement from a magazine or newspaper that used sex to sell the product and onc advertisement that did not use sex to sell the product. The conversation went:

Edward: David

David: Ah? Let me see. Better than your girlfriend. This one ah... [inaudible]

Edward: Not her. My girlfriend's a seventh grader.

David: My girlfriend's ah....ah...ah...my girlfriend is sixth grader.

Another conversation occurred while I was collecting quizzes. It was also about girls and went like this:

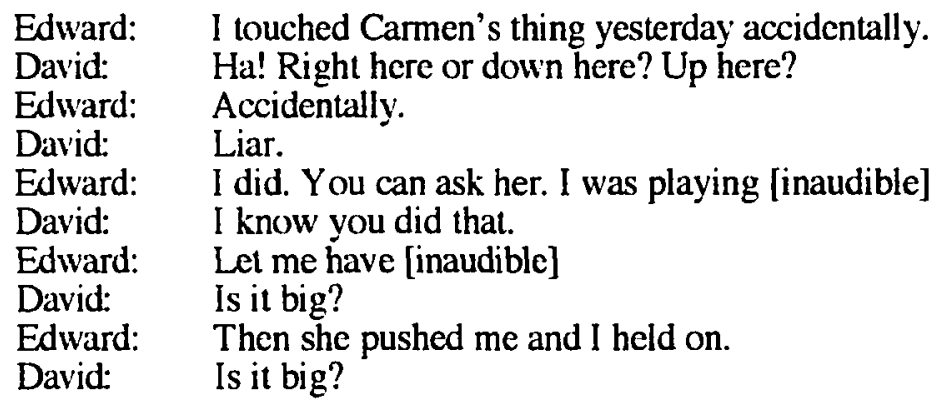

The conversation ended when Linda interrupted, asking who was collecting one part of the quiz. 
Once again, David's utterances were usually short. I noticed a different use of some of his statements in this group placement. A portion of David's language was simply repeating what I or another group member said.

$\begin{array}{ll}\text { Edward: } & \text { Umhuh } \\ \text { David: } & \text { Umhuh } \\ \text { Edward: } & \text { [inaudible] it goes here. } \\ \text { David: } & \text { It goes here. Goes here in the box. }\end{array}$

On another occasion:

MD: $\quad$ OK, sex appeal ads.

David: Sex appeal.

Another example:

MD: $\quad$ OK, what are your two groups? Let's see.

Linda: Feelings and no feeling.

David: Feeling and no feeling.

I am not certain whether David was practicing English or merely repeating previous statements for the sake of having something to say. Whatever his reason, this was not something that occurred in his first group placement.

In this group, David asked questions about the material being worked on. Of the 75 utterances recorded in this group, 21 were questions. That is, $28 \%$ of his utterances were in the form of questions (see Table 12). All of the questions were addressed to group

Table 12

Types of Utterances: David's Second Group Placement

\begin{tabular}{|c|c|c|}
\hline Type of Utterance & \# of Utterances & \% of total \\
\hline Questions & 21 & $28 \%$ \\
\hline Answers & 15 & $20 \%$ \\
\hline Statements & 39 & $52 \%$ \\
\hline Totals & 75 & $100 \%$ \\
\hline
\end{tabular}


members and almost all of them were specifically addressed to Edward. In the first cxample, the group was taking the same genetics quiz described in Minh's case study'

Edward and David were taking the quiz. Edward was attempting to point out an error in procedure to the girls at the table.

Edward: You don't circle it. You write it.

Linda: Da! I did write them.

David: $\quad$ Circle what? What are you talking about?

Edward: You're suppose to write them in here. Write the gene pairs you chose [inaudible].

David: Inside?

On another occasion, one of the sex education worksheets was being discussed as a whole-class activity. On the tape, I was heard saying, "B. Menstruation is the name for having a period." In the group, David asked Edward for clarification:

David: What is it?

Edward: $\quad$ B.

Another example of David asking for clarification occurred later in the same class discussion. Again, Edward responded to David's request.

Randy: $\quad F$

MD: $\quad F$, for sperm, is correct.

David: What?

Edward: $\quad$ Sperm [pause] F.

David: That's what I put.

Edward did not ignore David. On the contrary, he made an effort to include him. The girls in the group were not often involved with David. However, the tapes revealed that they did not try to tattle on him or belittle his efforts. That David was more involved in this group placement seemed to be related to Edward being a member of the group and to Edward's acceptance of David as a group member.

There were few examples of David being involved with the girls in the group. In two examples, he was attempting to provide information. In this first conversation, Shirley was attempting to write Linda's last name on a group paper, and was having difficulty.

David: Doesn't know how to spell, Shirley. 
Edward: I'm gonna go library. I'm gonna go library, Shirlcy.

David: Interation-E-n-tar-Nation.

Edward: [inaudible]

David then spelled his own last name for Linda who was acting as group recorder.

In the second instance, David responded to a question by Edward about the genetics quiz, and, after repcating Linda's response to Shirley, added additional information that Shirlcy needs.

Edward: What is EE?

David: $\quad$ Ed, look at me. It's eye. right there. There E. Stu-pid.

Shirley: $\quad$ Are we gold or what?

Linda: $\quad$ Gold two.

David: Gold twoononono. Table six.

This conversation demonstrated that David did have some understanding of this unit's science concepts. Edward was asking what trait a gene pair of dominant $E$ and dominant $E$ would contribute to the baby monster. David explained that this trait indicates eyes. In this group placement, $13 \%$ of David's utterances conveyed understanding of the unit's concepts (see Table 11).

In David's first group he was recorded on tape laughing only once. This was after he said the name Edgar as Edgan. He laughed at his mispronunciation and corrected himself. In the second group, laughter was recorded about things Edward or other group members said. These things were not jokes and I'm not certain what David found funny in this conversation, but his laughter may have reflected a feeling of greater comfort with this group.

Two important things I heard in this group that I did not hear in the other group was praise by another group member, Edward, and a verbal expression of feeling good by David.

David: (answering a teacher question) Testicles.

MD: $\quad$ David? Testicles, yes.

Edward: Alright, my man! 
After I announced the amount of tickets needed for an " $A$ " in the oral participation portion of the sex education unit to the class, David was heard on the tape saying, in a singsong voice, "I got an 'A." His group did not respond to this utterance, and there was no conversation in the group for about two minutes while I gave directions to the whole class. Then David said, "I feel good. I feel."

Once again, during the Family Life/Sex Education unit, I noticed that David, who had not volunteered once during his first group placement, began volunteering to answer questions during the large group setting. He did not answer all questions correctly but this did not keep him from attempting further answers.

\section{Findings From Attitudinal Surveys and Interviews.}

David's surveys indicated that he rated his work with this group as high and somewhat important. This was the question that he had skipped on his first two surveys. He enjoyed the activities (small group work followed by a long period of large group and pair activity) very much. He indicated he felt better about himself after the large group activity and about the same after the partner activity. His open-ended responses were: "After today's activity I felt..." "I felt good because we help together" and "very good and I leamed about things."

In this final interview, David told me he enjoyed working with his team the most because here the members talk to each other. He felt he learned more with his partner but communicated more when involved with his entire team. While with his whole cooperative group:

David: I work with and talk to ah... what's the answer...ah, I help them. MD: Oh, so you actually helped when you were with the team. OK, and you help when you were in the pair, or did your other partner help more?

David: $\quad$ My other partner was helping.

David felt helping, being a contributing member of the group, was important and he indicated this was his favorite group. When I asked him why, he replied: 
David: Because together work and like that and if you had another answer let them copy. And let them do another one.

I asked David if working with a cooperative group (a team) affects the way he feels about himself.

David: I feel better.

MD: $\quad$ You felt better. Why did you feel better?

David: $\quad$ Because working together in groups.

Again, he was expressing the importance of working together, being part of the group.

As with the other two students, I asked David about his increased participation in whole class discussions. I noted, in my field notes, and heard on the audio tapes, that David volunteered answers in his second placement, whereas, in the first placement, he would only answer if specifically called upon. I wanted to know if the giving of tickets had anything to do with the increased participation.

He said that before the tickets he used to raise his hand but I never called on him, then I started calling on him after the tickets. This was not my observation, so I asked him if he thought his hand was up more before the tickets or after we started doing tickets.

David: $\quad$ Before we started doing the tickets.

MD: $\quad$ Your hand was up more before we started tickets?

David: $\quad$ I mean after.

MD: $\quad$ After. What about getting tickets? Did that make you put your hand up more?

David: Yeah.

MD: Why did you put your hand up when you were getting tickets?

David: $\quad$ Because we get grade like that.

I closed the interview by asking David if he felt working in groups helped him learn English.

David: $\quad$ Yeah, because we talk.

MD: Without the groups? What?

David: $\quad$ Because we talk in groups. They teach me how to speak English.

MD: $\quad$ OK, they can teach you how to speak English. Is that better than

David: Yeah! Yeah! the teacher always trying to teach you English? 


\section{Summary of David's second group experience.}

In this group, David had a fricnd, Edward. His friend accepted him as a group member and this made David's experience positive. They discussed science assignments and personal things. While the girls in the group did not actively involve David, neither did they actively try to exclude him. The majority of David's communications in this group were not arguments. He asked more questions, most of them addressed to Edward. He did answer a few questions within his group. He was heard laughing and a few of his answers reflected an understanding of the science concepts being taught. David participated more of ten in whole class discussions. His surveys and interview reflected that he felt he made a contribution to this group and, after working with this group, he had positive feelings about himself.

\section{Comparison of David's Two Group Placements.}

David's first group experience was not the positive experience his second placement was. In the first group, David did not ask as many questions as in his second group. He did however, spend much more time arguing in the first group. The girls in the first group, especially Mary, made no secret of their dislike for David. This was in contrast to the friendship he had with Edward in his second group. In his second placement, David was heard laughing, expressing some understanding of science concepts, and even expressing good feelings about himself.

Through the surveys and interview, David revealed that he felt better about himself when he worked together with his group, contributing or helping. David wanted to be a full group member. When he was able to contribute during an activity, he felt better about himself. The group placement and the opportunity for David to contribute as a group member emerged as important factors in how David felt about himself and his work. 


\section{Cooperative Group Placement: An Important Factor}

The comparison of each student's two placements reveaied that for each student one of the group placements was a more positive experience. This is not to say that the other group placement was a negative experience; rather it was less beneficial in creating an environment for the enhancement of the student's self-esteem.

In reviewing each of the ENNL student's more positive placements, I found five elements in common. Each more positive placement had:

a) Participation in the group activity by the ENNL student.

b) Treatment of the ENNL student as an active CL group member.

c) More two-way conversations took place between the ENNL student and the English-speaking students.

d) A feeling of self-worth and importance of his or her contributions to the group was reflected in the attitudinal surveys of the ENNL student.

c) An expression of being part of the cooperative group team, of helping and being helped, was expressed during the interviews by the ENNL student.

Based on these five elements, each of the ENNL student's more positive group placement is discussed.

For Chandra, the second group placement was the more positive experience. In this group, Chandra was involved in helping the team or his partner complete the task. While in the first group he was often not involved in the activity at the team level and often chose to complete the task on his own. In the second group placement, Chandra was treated as a CL group member. Here, Chandra was engaged in two-way conversations with his team members and was heard laughing and joking. In the first group placement there were few two-way conversations. Chandra's communications in this group were mainly statements, to which his group often did not respond. Chandra's language in both groups did reflect an understanding of science content. His second group utilized his knowledge within the 
group activities. His first group did not. Chandra's surveys and intervicws indicated that he did not feel good about himself or his work with the first group. In the interview following his first group placement, he expressed wanting to feel needed and wanting to help the group. These "needs" were met in his second group. Here, he felt better about himself and his work. He rated his role in helping the group as important compared to unimportant in his first group. In his own words, Chandra explained that the second group was his best group, "Because we all do work and no is left out and you all get to work".

For Minh, the more positive group placement was her first group placement. In this group placement, Minh was active and involved in the group activities. In her second group, she was active and involved only when engaged in a partner activity and then only when working with her regular group partner. (At the end of this group experience, her regular team partner was absent and she was paired with a girl from another team.) In the first group, Minh was treated as a $\mathrm{CL}$ group member. In observing and listening to the audio tapes, Minh's contributions were included in the group work, her questions were responded to, and the group would wait for her to catch up. Her communications in her first group did reflect some understanding of science concepts and were most often twoway conversations. In the second group, her communications with her partner were twoway conversations, although these types of communication did not carry over to the full $\mathrm{CL}$ group. The small amount of conversation she had with the entire group in her second placement had little to do with science concepts or the science activities. Her few comments seemed to be addressed to one boy asking him to be quiet and to quit engaging in behaviors Minh thought were inappropriate. Minh's surveys and interviews reflected that in her first group experience she felt good about herself and her work. She felt she contributed to the group. During the second group experience, Minh indicated her work was not as important and she did not feel as good about herself. Minh explained in her interview following the 
lirst group placement, "The group was working together...I only work by myself I can't do it. But, with them I could do it."

The second group placement was the more positive one for David. In this group, David was more involved in both the group and partner activities. He engaged in two-way conversations. The only two-way communication David had with his first group was during arguments. In fact, arguing was the main type of communication that took place between David and his first group. The first group seldom gave David the opportunity to participate in the group activity. This was not true of the second group. This group, especially Edward, treated David as a CL group member, responding to his questions and listening to him. In the second group placement, David was actually heard laughing. On the surveys taken while in the first group, David did not respond when asked to rate his part in helping the group. On the surveys during the second placement, he responded both times, saying his work was somewhat important. His interview indicated that in the second group David felt better about himself and his work than in the first group. He indicated that this was the team he enjoyed the most because, "I work with and talk to ah...what's the answer...ah, I help them...Because together work and like that and if you has another answer let them copy. And, let them do another one." 


\section{Chapter Five \\ A Discussion of the Data}

\section{Introduction}

In this chapter, the relationship between the data and the original question is explored-Does cooperative learning affect an ENNL student's self-esteem? The chapter begins with a discussion addressing this question. Next the subquestions regarding the ENNL students' roles in the group are discussed. The chapter then continues with a discussion of questions and issues raised by this study. The chapter ends with possible implications for the classroom.

\section{Cooperative Learning and Self-esteem}

For cach of the three students, one group placement emerged as a more positive group placement. There were five elements that were common to a positive group placement listed in Chapter 4. The fourth of these five elements was that the students felt self-worth and they felt their work was important to the group. This element leads back to the original question. Does cooperative learning have an effect on an ENNL student's self-esteem? I must answer that question affirmatively when speaking of Chandra, Minh and David. The determining factor, according to the students' surveys and interviews, was not the type of CL activity, but whether the student was a contributing CL group member during the activity. Whether the ENNL student was a contributing CL group member was dependent on the group placement and group make-up. In a positive group placement, the ENNL student participaled as a full group member. He or she participated in the science activity, shared answers and engaged in two-way conversations. While in a positive group placement the students' self-esteem, as reflected in the surveys and the interviews, remained the same or increased. The responses indicated that the students sometimes felt 
better about themselves, but never worse. This was not seen in the less positive group placement. Mihn and Chandra both indicated they actually felt worse about themselves after one cooperative activity. Neither indicated they felt better about themselves while in the less positive placement.

In a positive group placement, the ENNL students saw their work as having value and their role in the group as important. They helped their groups achieve their goals and accomplish their tasks. Over and over, these students told me how they felt better about themselves in a group where they were a part of what went on. When I asked them why the less positive groups were less positive, or why they didn't enjoy the activity, or why they did not think their work was important to the group, they replied that the group didn't let them do anything. They were not allowed to participate, no one helped them, or no one let them help.

\section{Revisiting the Subquestions}

Subquestions led to the original question asked in this research. Answering these subquestions reiterates the importance of the ENNL students' group placements. The questions were:

1) What roles are ENNL students playing in their CL groups?

2) Are they full-fledged team members, intimately involved with the group task, or are they simply sitting uninvolved among the team members?

3) Does their participation in the group, or lack thereof, have an effect on their self-esteem?

The roles of the ENNL students differed from placement to placement. The roles they played depended on whether or not they were considered a full group member. If they were accepted as a member of the team they were included in the group task. The ENNL students were circuit builders or material getters. They offered suggestions and asked and answered questions. This was seen in each of the students' positive placements. 
If the ENNL students were full group members they contributed to the group product or process. Their comments and work were discussed rather than ignored. Their contributions would be included in the group work final product that was turned in to the teacher. Again, this type of interaction and inclusion of ENNL students' comments and work was seen in the positive group placement. In the less positive placement, the ENNL students' comments were often ignored and the group would even attempt to exclude them from participating in or contributing to the CL activity. It is sad to say that if students were not considered full group members, they could sometimes be seen sitting uninvolved among the team members.

In looking at the last subquestion, dealing with the ENNL students' participation in the group affecting their self-esteem, one need only look at the five elements of a positive placement to answer a resounding yes. All five elements relate to the ENNL students' participation. In a positive placement, the ENNL student participated in the activity and had two-way conversations with other group members. They were treated the same as other participating group members. Their participation in the $\mathrm{CL}$ group contributed to a feeling of self-worth and the importance of their work. Participation made them feel they were helping and being helped by the CL group. And, as previously stated in this chapter, in a positive group placement an ENNL student sometimes felt better about themselves after a CL activity, but they never felt worse. This cannot be said of the less positive placement.

\section{Questions Raised by this Research}

As is often the case in the research process, for each question answered, several more questions are raised. This happened during my research. In this section questions raised by this research are examined and possible implications for the classroom are discussed. 


\section{Teaching Additional Social Skills}

One of the tenets of CL, according to Johnson et. al, (1986) and Kagan (1992), is the teaching of social skills. In the science lab, social skills were taught, as well as posted on the wall: make eye contact, take turns, assist others, share, make comments positively, encourage and praise others. If students were learning and using these social skills, then the question is, why did the less positive group placements occur? These social skills did not seem sufficient to bridge the gaps between the English speakers and the ENNL students. Teaching about eye contact and praising others did not seem to give most of my English speakers the tools, the skills, they needed to involve the ENNL students in the CL tasks or as full group members. Nor did this teaching create an empathy for what the ENNL students were experiencing in the English dominant classroom. Could this be done through social skills teaching? Perhaps the teaching of social skills in CL needs to be expanded when ENNL students are included in the CL groups so more positive group placements can be created.

In teaching the social skills, teachers create an awareness of the need for the skills. This can be done through direct instruction, modeling, and role playing. Teachers reinforce the desired skills by pointing them out during CL tasks and by having the students reflect on how they used the skills they had been taught during the processing or debriefing time.

What if a new social skill, "consider each other's feelings," is added to the list? While teaching this new skill, teachers could create an awareness within the CL group of the ENNL student's needs. The teacher could model how to communicate with the ENNL student and methods for involving them in the CL group and the CL activity. Could this help create the more positive group placements I saw during this study? This research cannot answer this, but I believe it is a question worthy of further investigation. 


\section{A Guided Debrief}

Processing time for groups to reflect on how they performed as a group is another essential part of CL. This debriefing time is also when the students have the opportunity to discuss ways to improve the group performance for their next activity. An opportunity to create an awareness of the difficulties that an ENNL student may be having within the group, and possible methods for reducing these difficulties, may lic in this processing time after the activity.

I missed the opportunity to specifically deal with the ENNL students during this time. In the future, I will include during some of our processing time questions about who participated the least and why. This question would be followed up with one asking for specific suggestions on how to include this person next time. The person least involved is often, but not always, the ENNL student. Phrasing the questions this way would not single out the ENNL student and allow the group to reach its own conclusions.

Debriefing can also be done in a teacher-led format where the whole class discusses what happened in their groups. Again, with the same type of guided questions, this could allow the opportunity for groups to share and learn about strategies for involving ENNL students from each other. Finally, if full group involvement in the activity is truly valued, a teacher needs to assess for this while observing the group process. Including feedback in this area on a teacher $\mathrm{CL}$ group observation sheet or giving it value as part of a CL group process grade are possible ways to add it to the CL assessment process. This assessment could be shared with $\mathrm{CL}$ teams during the debriefing time.

\section{ENNL Student Input Regarding Group Placement}

I allowed input from the students in their last group placements. I allowed them, within certain parameters, to choose their own CL groups. For Chandra and David, this second group placement was the more positive experience. For Minh, it was not. Minh 
arrived lardy for class that day, and therefore began at the end of the new group formation process. She had to pick from the leftover seats at existing tables. The teams that the ENNL students placed themselves in were heterogeneous, as were the groups I had placed them in. Although Minh's overall group placement was less positive than her first group, her partner experience exhibited the five elements I found present in the positive group experience.

This choosing of their own CL groups occurred near the end of the year after the process of forming new groups without verbal or nonverbal put-downs had already been discussed, modeled and engaged in through the forming of two previous groupings. Allowing the students to choose their own groups may not have been as successful had it been done at the beginning of the year. Another method that I have used to oblain student input in the forming of groups that may work for obtaining ENNL student input is to have the students choose one other student they would like to have in their group placement. The students write down the name and reasons why they would like to work with their choice on a secret ballot. They also have the option of indicating that they have no preference. This is not discussed among the students, nor do the ballots become public knowledge. Important criteria for selecting a possible group member are discussed prior to the students making their choices. I then form the groups after considering the student input. I have never used this to specifically gain input from the ENNL students in the past, but I can foresee using it for this purpose in the future.

Something else that struck me as I observed and listened to the ENNL students in their CL groups was that two of the ENNL students, Minh and Chandra, spent a good portion of their time helping two learning disabled students, one in each of their groups. Vicki, in Minh's group, and Ned, in Chandra's group, both had a difficult time communicating in writing. In both cases, the ENNL students took a leadership role in supporting the learning disabled students during the science activity. 
These obscrvations regarding ENNL students' including a learning disabled student in their $\mathrm{CL}$ group composition raise some interesting questions. Did having another group member that also struggled in some way with language make for a group in which the ENNL students could function in the role of leader and helper? Do ENNL students and learning disabled students recognize in each other the common, shared experience of struggling to communicate? Or, was it just a coincidence that in each of the groups with a learning disabled student the ENNL student helped and supported that student? Did the ENNL students intentionally choose a learning disabled student? This research is much too limited to address these questions.

\section{Continued Use of Attitudinal Surveys}

I found the attitudinal survey to be a valuable tool in gauging how my students feilt about themselves while in a group. Perhaps the one discovery from this research that has caused the most concern for me is that on the surface a $\mathrm{CL}$ group may seem to be functioning fine, but it may, in fact, not be functioning well at all. Taping groups is a wonderful way to find out what is really happening in a group, although it is not often practical for the already overworked instructor. The attitudinal survey, given periodically, could give the teacher an indication that something in the group may be adversely affecting a student. This survey could provide a "red flag" indicating the need for a closer examination of a particular group.

Another option that could provide the teacher with the students' feedback regarding their CL groups, would be a dialog journal. Here, the students could respond to writing prompts about their groups provided by the teacher. The teacher would have a "discussion" about the $\mathrm{CL}$ groups with the students through their journals. 
Increased Oral Participation by ENNL Students in Whole-Class Setting

One of the most interesting things I observed during my project was that when I introduced the tickets for oral participation, all three ENNL students' level of participation in whole class discussions increased. The student did not always answer the sex education question being discussed correctly. However, whether their answer was correct or incorrect, their hands were almost immediately back in the air, volunteering to answer another question. The ENNL students explained that the increased level I observed was duc to two things: they knew the material (the answers) and they knew the tickets would help their grades. Since I always explain to my students that oral participation affects their grade, why did giving them the tickets make such a difference?

This raises some other interesting questions. If I offer tickets at other times during the school year, would I have seen the same increase in oral participation in the large group setting? Does the immediate, tangible reward of the tickets, which ultimately would be used to calculate the ENNL students' oral participation grades, cause the increase? Again, these questions are not answered in this study, but this "ticket" system could be tried in the future to see if there is increased oral participation by ENNL students.

\section{Classroom Implications}

This research project raises some very interesting questions, questions that I hope I, or another teacher-researcher, may someday have the opportunity to investigate further. Answering these questions will lead to some classroom implications, just as this research has.

As a result of this project, I have become aware of the importance of the group placement for the ENNL student. A positive placement can positively affect an ENNL student's self-esteem. Just as importantly, a less positive placement can have an adverse effect on these students' self-esteem. If possible, all students should be placed in positive 
placements. Unfortunately, this research does not provide a blueprint for creating these positive group placements. It did, howerer, find five things in common in these types of placements:

1) Participation in the group activity by the ENNL student.

2) Treatment of the ENNL student as an active CL group member.

3 More two-way conversations took place between the ENNL student and the English-speaking students.

4) A feeling of self-worth and importance of his or her contributions to the group was reflected in the attitudinal surveys of the ENNL student.

5) An expression of being part of the cooperative group team, of helping and being helped, was expressed during the interviews by the ENNL student.

To assure that an ENNL student is in a positive placement, a teacher can observe the ENNL student's group interaction and involvement in an activity or project. This will begin to create a picture of the group placement and of how the ENNL student is treated and valued as a group member. Also the teacher needs to listen for two-way conversations between an ENNL student and other group members. This will add additional details to the picture of the group placement. This listening objective can occur during the teacher's facilitation of the groups during a CL activity or while assessing the CL process.

To complete the picture of whether the ENNL student is involved in a positive group placement, a teacher must find a way to gauge the ENNL student's feelings regarding selfworth and the importance of his or her contribution to the cooperative group. Somehow, a teacher must determine if the ENNL student feels a part, a helping and contributing part, of the CL team. This could be done through the use of an attitudinal survey, as in this study. It could be done by having students reflect orally or in writing on an open-ended question such as, "I am important to my CL group because..." It may be possible to discover this through the debriefing process as discussed earlier. What is important is that somehow a 
teacher needs to establish whether the CL group that the ENNL student is in, is a positive placement.

This research project reinforces one of the important distinctions between CL groups and small groups. The teacher must play an active role in the facilitation of the CL groups. A teacher's job does not end with assigning the members of the groups, or giving the assigned task, or even with designing the roles the members of the group will play in their group. It continues with the teaching and modeling of social skills. Further, it includes observation of the group process and feedback to the group regarding what is observed. A teacher's involvement is essential for creating the environment necessary for successful use of CL strategies.

Cooperative learning is not a miracle method guaranteed to develop English for an ENNL student in a heterogeneous classroom. It does, however, offer promise and it certainly warrants additional research in the area of the self-esteem of ENNL students relative to their CL group placements. 


\section{References}

Ascher, C. (1986). Cooperative learning in the urban classroom. ERIC/CUE Digest. (ERIC Document Reproduction Service No. ED 273717)

Bejarano, Y. (1987, September). A cooperative small group methodology in the language classroom. TESOL Quarterly, 21, 483-504.

Brown, H. D. (1987). Principals of language learning and teaching. Engelwood Cliffs, NJ: Prentice Hall.

Calderón, M. (1989). Cooperative learning for LEP students. Intercultural Development Research Association Newsletter, 16, 1-7.

Charles, C.M. (1988). Introduction to educational research. White Plains, NY: Longman.

Cohen, E. G. (1990). Continuing to cooperate: prerequisites for persistence. Phi Delta Kappan, 72, 134-136, 138.

Conwell, C., Piel, J., \& Cobb, K. (1988, November). Students' perceptions when working in cooperative problem solving groups. Asheville, NC. Paper presented at North Carolina Science Teachers Association Convention. (ERIC Document Reproduction Service No. ED 313455)

Cummins, J. (1981). Four misconceptions about language proficiency in bilingual education. NABE Journal, 5, 31-45.

Cummins, J. (1984). Bilingualism and special education: issues in assessment and pedagogy. San Diego, CA: College-Hill.

deAvila, E. (1987). Finding out descubrimiento. Northvale, NJ: Santillana.

Ellis, R. (1986). Understanding second language acquisition. Oxford: Oxford University Press.

Gallien, L. B. (1988, August). Cooperative learning: observations and reflections in context with minority achievement and educational reform. Starkville, MS: Paper presented to the Association of Teacher Educators summer workshop. (ERIC Document Reproduction Service No. ED 302502)

Hakuta, K. (1986). Mirror of language. The debate on bilingualism. New York: Basic Books.

Handscombe, J. (1989). A quality program for learners of English as a second language. In P. Rigg \& V. Allen (Ed). When they don't all speak English (pp. 114). Urbana, IL: National Council of Teachers of English. 
Jacob, E. \& Mattson, B. (1987). Cooperative learning with limited-English-proficient students. Washington, DC: Center for Applied Linguistics. (ERIC Document Reproduction Service No. ED 287314)

Johnson, D. M. (1992). Approaches to research in second language learning. White Plains, NY: Longman.

Johnson, D. W., Johnson, R. T., \& Holubec, E. J. (1986). Circles of learning: cooperation in the classroom (rev. ed.). Edina, MI: Interaction Book.

Kagan, S. (1992). Cooperative learning. San Juan Capistrano, CA: Kagan Cooperative Learning.

Krashen, S. (1982). Principles and practice in second language acquisition. Oxford: Pergamon.

LeCompte, M. D. \& Goetz, J. P. (1982). Problems of reliability and validity in ethnographic research. Review of Educational Research, 52, 31-60.

Levine, L. N. (1984). Content area instruction for the elementary school ESL student (Report No. F 4016005). Houston, TX: Paper presented at annual convention of Teachers of English to speakers of other languages. (ERIC Document Reproduction Service No. ED 274182)

Long, M. H., \& Porter, P. A. (1985). Group work, interlanguage talk, and second language acquisition. TESOL Quarterly, 19, 207-227.

Meyers, M. (1993). Teaching to diversity. Teaching and learning in the multi-ethnic classroom. Menlo Park, CA: Addison-Wesley.

National Education Association (1982). Cooperative learning: student teams (Report No. 1055-8-00). West Haven, CT: National Education Association Professional Library. (ERIC Document Reproduction Service No. ED 222489)

Olsen, L. (1988). Immigrant students and California public schools. Crossing the schoolhouse border. San Francisco, CA: California Tomorrow.

Olsen, L. (1991). The unfinished journey: restructuring schools in a diverse society. San Francisco, CA: California Tomorrow.

Olsen, L. \& Mullen, N. (1990). Embracing diversity. Teachers' voices from California classrooms. San Francisco, CA: California Tomorrow.

Slavin, R. (1988, October). Cooperative learning and student achievement. Educational Leadership, 31-33.

Solomon, D., Battistich, V., \& Delucchi, K. L. (1990, August). Cooperative learning, intragroup dynamics, and student outcomes. Boston, MA: American Psychological Association. (ERIC Document Reproduction Service No. ED 326817) 
Williams, C. (1992). Ingredients for an effective instructional environment. Paper presented at Language Development Specialist review class in May, 1993.

Yager, S., Johnson, R. T., Johnson, D. W., \& Snider, B. (1985). The effect of cooperative and individualistic lcaming experiences on positive and negative crosshandicap relationships. Contemporary Educational Psychology, 10, 127-138. 


\section{Appendix A}

\section{Survey Form}

\section{Student Attitudinal Survey}

Name

Datc

1) How do you rate your work in this activity?

High Medium Low

2) How' did working on today's activity make you feel about yourself?

$$
\text { Better About the same Worse }
$$

3) Did you enjoy today's activity?

Very much It was OK Not at all

4) Rate how much you like school after working on activities like the ones that you participaled in today.

$$
\text { More Less The same }
$$

5) Rate the amount of pressure you felt to participate in today's activity.
A lot of pressure
Some pressure
No pressure

6) After today's activity I felt

7) How do you rate your part in helping your group solve the problem?

Important Somewhat important Unimportant

8 a) Who helped the most within the group?

8 b) Who helped the least within the group? 